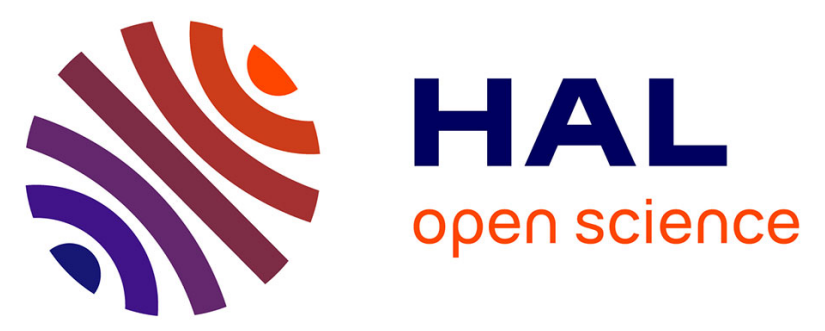

\title{
SIc-Abacus: An in-situ tool for estimating SIc and Pco2 in the context of carbonate karst
}

\author{
N. Peyraube, R. Lastennet, A. Denis, S. Minvielle, N. Houillon, G. Lorette, P. \\ Malaurent, S. Denimal, C. Bertrand, Stéphane Binet, et al.
}

\section{- To cite this version:}

N. Peyraube, R. Lastennet, A. Denis, S. Minvielle, N. Houillon, et al.. SIc-Abacus: An in-situ tool for estimating SIc and Pco2 in the context of carbonate karst. Journal of Hydrology, 2019, 568, pp.891-903. 10.1016/j.jhydrol.2018.11.042 . insu-01936654

\section{HAL Id: insu-01936654 https://hal-insu.archives-ouvertes.fr/insu-01936654}

Submitted on 27 Nov 2018

HAL is a multi-disciplinary open access archive for the deposit and dissemination of scientific research documents, whether they are published or not. The documents may come from teaching and research institutions in France or abroad, or from public or private research centers.
L'archive ouverte pluridisciplinaire HAL, est destinée au dépôt et à la diffusion de documents scientifiques de niveau recherche, publiés ou non, émanant des établissements d'enseignement et de recherche français ou étrangers, des laboratoires publics ou privés. 


\section{Accepted Manuscript}

Research papers

SIc-Abacus: An in-situ tool for estimating SIc and $\mathrm{PcO}_{2}$ in the context of carbonate karst

N. Peyraube, R. Lastennet, A. Denis, S. Minvielle, N. Houillon, G. Lorette, P. Malaurent, S. Denimal, C. Bertrand, S. Binet, C. Emblanch, F. Naessens, N. Asmael, J.D. Villanueva

PII: S0022-1694(18)30897-7

DOI: $\quad$ https://doi.org/10.1016/j.jhydrol.2018.11.042

Reference: $\quad$ HYDROL 23283

To appear in: $\quad$ Journal of Hydrology

Received Date: $\quad 4$ October 2018

Revised Date: $\quad 14$ November 2018

Accepted Date: $\quad 15$ November 2018

Please cite this article as: Peyraube, N., Lastennet, R., Denis, A., Minvielle, S., Houillon, N., Lorette, G., Malaurent, P., Denimal, S., Bertrand, C., Binet, S., Emblanch, C., Naessens, F., Asmael, N., Villanueva, J.D., SIc-Abacus: An in-situ tool for estimating SIc and $\mathrm{PcO}_{2}$ in the context of carbonate karst, Journal of Hydrology (2018), doi: https:// doi.org/10.1016/j.jhydrol.2018.11.042

This is a PDF file of an unedited manuscript that has been accepted for publication. As a service to our customers we are providing this early version of the manuscript. The manuscript will undergo copyediting, typesetting, and review of the resulting proof before it is published in its final form. Please note that during the production process errors may be discovered which could affect the content, and all legal disclaimers that apply to the journal pertain. 


\title{
SIc-Abacus: An in-situ tool for estimating SIc and $\mathrm{Pco}_{2}$ in the context of carbonate karst
}

\author{
N. Peyraube ${ }^{1 *}$, R. Lastennet ${ }^{1}$, A. Denis ${ }^{1}$, S. Minvielle ${ }^{1}$, N. Houillon ${ }^{1}$, G. Lorette ${ }^{1}$, P. \\ Malaurent $^{1}$, S. Denimal ${ }^{2}$, C. Bertrand ${ }^{2}$, S. Binet ${ }^{3}$, C. Emblanch ${ }^{4}$, F. Naessens ${ }^{1}$, N. \\ Asmael $^{5}$, J. D.Villanueva ${ }^{6}$
}

${ }^{1}$ Université de Bordeaux, UMR 5295 I2M-GCE, Bordeaux, France

${ }^{2}$ Université de Franche-Comté, UMR 6249 Chrono-Environnement, Besançon, France

${ }^{3}$ Université d'Orléans, UMR 7327 ISTO, Orléans, France

${ }^{4}$ Université d'Avignon et des pays Vaucluse, UMR 1114 EMMAH, Avignon, France

${ }^{5}$ Univeristy of Damascus, Department of Geology, P.O.65735, Damascus, Syria

${ }^{6}$ University of the Philippines Los Baños, SESAM, College, Laguna, Philippines

*Corresponding author: nicolas.peyraube@u-bordeaux.fr

\section{ABSTRACT}

This article aims to provide an on the spot, handy field tool that can be used in estimating the Saturation Index with respect to calcite in karst aquifers in a limestone context. It relies on an abacus that gives the SIc by using measured $\mathrm{pH}$ and bicarbonate concentration as coordinates.

The analytical expressions of the carbonate equilibrium equations are derived in order to calculate SIc from values that can be measured on field. Using these established relationships, we propose an Abacus built from the $\mathrm{SIc}=f\left(\mathrm{PcO}_{2} \mathrm{eq}\right)$ reference frame, hence called SIc-Abacus.

Accuracy of SIc calculation is also discussed. SIc is calculated with values measured considering uncertainty coming from $\mathrm{pH}\left( \pm 0.05 \mathrm{pH}\right.$ units), temperature $\left( \pm 0.1^{\circ} \mathrm{C}\right)$, bicarbonate and calcium concentrations $( \pm 2.5 \mathrm{mg} / \mathrm{L}$ and $\pm 2 \mathrm{mg} / \mathrm{L})$. This gives, for each sample, a range of possible SIc values of $\pm 0.060 \mathrm{pH}$ units (for a bicarbonate concentration close to $300 \mathrm{mg} / \mathrm{L}$ ). The effect on SIc range of possible values given by bicarbonate and calcium uncertainties is about 10 times lower than the effect brought by $\mathrm{pH}$ uncertainty. Also, bicarbonate and calcium concentration can be estimated from electrical conductivity leading to a possible range of SIc value of $\pm 0.087 \mathrm{pH}$ units. In both cases, the range of possible values of SIc varies according to the bicarbonate concentration.

Using Cussac and Lascaux sites, an evaluation was done. Results show the goodness of fit $\left(\mathrm{R}^{2}=0.96\right)$ between the calculated SIc from measured $\mathrm{pH}$, bicarbonate and calcium concentration and the estimated SIc values generated from the SIc-Abacus. Apart from calculating SIc, another method which is an alternative use of the generated SIc equation focused on obtaining $\mathrm{pH}$ using parameters such as electrical conductivity and dissolved $\mathrm{CO}_{2}$ measurements is presented.

The study shows that SIc-Abacus can be a new in-situ tool for karst aquifer surveys. It can facilitate in making a swift decision that tackles carbonate karst issues (e.g. when selecting sites or in deciding if extensive monitoring should be performed or not based from a specific objective).

Keywords: Bicarbonate, Saturation Index, SIc-Abacus, field tool, $p H$ 


\section{Introduction}

Karst aquifers are mainly developed in limestone areas (Ford and Williams, 2007). These aquifers can represent a large source of water supply. Extensive monitoring of the water chemistry helps in defining the complex functioning of the aquifers. The ability of water to dissolve or precipitate calcite is characterized by the Saturation Index with respect to calcite (SIc). Evaluation of SIc is important in giving essential information of the karst system. For example, cartography of SIc in different stream sites can be performed for resource spatial evaluation (Herman and Lorah 1987; Pentecost 1992; Hess and White 1993; Keppel et al., 2012). It is also useful when calcite deposition/removal in stream water issued from karstic spring is a concern (Dreybrodt et al. 1992; Bono et al. 2001; Hattanji et al. 2014; Abongwa and Atekwana 2015). The SIc assessments can also describe the severity/progression of the precipitation of calcite enhanced by microbial activities in a supersaturated water (Cantonati et al. 2016).

In order to get information, normally, water samples should be analyzed at the shortest time in the laboratory. Then based from the findings, one can assess the saturation level of the spring or the water resource. The activities are tedious, time consuming and costly, (e.g. if large number of water samples are needed). SIc is often calculated using some software for geochemical modelling such as PHREEQC (Caboi et al., 1993; Cooper et al., 2002; Dreybrodt et al., 2011; Kanduč et al., 2012; Yan et al., 2016) or WATEQ4F (Edmunds et al., 1987; Mcdonald et al., 2007; Panda et al., 2017) or WATSPEC (Liu et al., 2007; Yang et al., 2012; Pu et al., 2015). Calculation can also be done directly in spreadsheet software using the equations of SIc presented by Langelier (1936). However, to immediately obtain a value of SIc using these software, one should use and/or bring a computer on field. The latter may be difficult as it can pose additional weight or bulk during the sampling campaign. 
There are times that a quick and one time estimation to provide a SIc information for a site is needed. This, for instance, can give an idea if the karst spring or site can be worth assessing with respect to the research objectives (e.g. environmental suitability) with less effort (sampling and laboratory analysis), time and cost. To date, there is still no handy tool that can provide a direct and prompt estimation of SIc on field (in-situ). For this reason, a solution for SIc estimation is proposed: field measurements of $\mathrm{pH}$ and bicarbonate concentration are placed in an abacus to estimate SIc on the spot. The abacus is named SIc-Abacus. It does not, however, replace a real calculation of SIc using modeling software and laboratory measurements of majors ions. This is a field tool to 1) facilitate in performing extensive acquisition campaign of SIc values on a certain region and 2) aid in making decisions if a full sampling of a karstic spring is needed or worth of doing. The SIc-Abacus is provided with a consideration on the consequences of the uncertainty of $\mathrm{pH}$, bicarbonate and calcium on the SIc value. In the limestone context, calcium and bicarbonate concentrations are essential water chemistry parameters. These two ions are often considered as the main ions of water in the absence of important sources of magnesium (dolomite) or sulfate (gypsum). Also, calcium and bicarbonate ions are important, with the $\mathrm{pH}$, if the ability of water to dissolve or precipitate calcite is a concern.

SIc-Abacus relies on the following conditions: 1) calcium and bicarbonate are proportional; 2) bicarbonate can be calculated from electrical conductivity; and 3) water acidity comes from dissolved $\mathrm{CO}_{2}$. These parameters are used as their relationships are already known and presented by several authors (Groleau et al., 2000 Krawczyk and Ford 2006, Liu et al., 2007). The margins of error of these relationships are discussed using a data set corresponding to the combination of field data that we acquired through time. Among the data set, Cussac and Lascaux sites in Southwest of France are presented more in detail and used to evaluate the accuracy of the proposed SIc-Abacus. 
In this article, the development and use of SIc-Abacus are discussed in sections. First, it presents the equations used to develop the abacus on spreadsheet software. Second, the accuracy of the abacus is discussed with the consideration of the consequences of the uncertainty of $\mathrm{pH}$, bicarbonate and calcium measurements on the SIc value. Third, a solution to obtain rough estimates of field values was proposed and the consequences on SIc accuracy using the abacus were examined. Forth, using Cussac and Lascaux as sites, the generated SIc values were compared to the SIc values derived from measured temperature, $\mathrm{pH}$, bicarbonate and calcium concentrations. Lastly, as the data permits, with Lascaux site, an alternative use of the SIc equation is shown (i.e. calculating $\mathrm{pH}$ ). In this light, continuous measurements of conductivity and dissolved $\mathrm{CO}_{2}$ were used as parameters.

\section{Data set and site background}

\subsection{Data set}

In this study, a data set is used to verify the relationships between field parameters (electrical conductivity, temperature, $\mathrm{pH}$, major ions concentrations including bicarbonate and calcium). The data set was obtained combining 1152 samples, from different springs $(\mathrm{n}=55)$. The samples were acquired sporadically within 25 years (1990 to 2015) in 4 different areas in France: Provence (Southeast), Perigord (Southwest of France), Pyrenees (South) and Jura (Northeast). The sampling campaigns were not done at the same period: some were done in 1991 (in the Southeast of France), others were done from 2003 to 2006 (in the South of France), and others were performed during 2015 (in the Southwest of France). For further details, specific site descriptions, materials and sampling methods are presented in the study of Lastennet and Mudry (1997) for the Provence sites, Binet et al., 2005 and 2017 for the Pyrenees site, Peyraube et al., 2012 and Minvielle et al., 2015 for the Perigord sites, Charlier et al., 2012 and Denimal et al., 2017 for the Jura sites. Climate conditions slightly differ with 
respect to the site and the year. Table 1 provides the average temperature, rainfall and localization for the four areas (Provence, Perigord, Pyrenees, and Jura). All meteorological data are obtained from Météo France, French meteorological survey agency.

The data set is used for its statistical worth (Table 2). It helps in assessing the margin of error of the relationship between calcium and bicarbonate concentrations and between bicarbonate concentration and electrical conductivity. Then, the samples taken from different springs were treated as a whole. This means that each spring is not considered separately from other springs, rather, presented altogether in the figures and tables. The data set combined field measurements of electrical conductivity, $\mathrm{pH}$ and temperature. Bicarbonate concentrations in $\mathrm{mg} / \mathrm{L}$ were measured on field (in situ) with colorimetric method. Alternately, bicarbonate concentration can be measured in the laboratory with $\mathrm{pH}$ titration at the very least time after water sampling. Major ion concentrations (calcium, sodium, potassium, magnesium, chloride, sulfate and nitrate) were measured using atomic absorption spectrometer or liquid chromatography.

\subsection{Selected Sites For SIc-Abacus Assessment}

For the evaluation of the tool, Cussac and Lascaux sites are discussed in detail. Both are located in Perigord, Southwest France (Figure 1). Climate is temperate, with a mean annual temperature close to $13^{\circ} \mathrm{C}$, a mean summer temperature between $22^{\circ} \mathrm{C}$ and $23^{\circ} \mathrm{C}$, and a mean winter temperature between $2^{\circ} \mathrm{C}$ and $3^{\circ} \mathrm{C}$. The mean annual precipitation varies between $800 \mathrm{~mm}$ and $1000 \mathrm{~mm}$. Evapotranspiration leads to a computed infiltration ranging from $200 \mathrm{~mm}$ to $350 \mathrm{~mm}$ per year (data provided by Météo-France, French meteorological service). Land cover consists of chestnut tree, oak, and pine trees. 
In Cussac site, water was sampled in Farfal spring. The spring comes from a small aquifer in Campanian (83.6 to 72.1 Million years) calcareous sandstone (limestone with large proportion of sandstone). The spring appears as a small pond of $8 \mathrm{~m}^{2}$ and $30 \mathrm{~cm}$ depth. Discharge is around $432 \mathrm{~m}^{3} /$ day. Water chemistry shows predominance of calcium and bicarbonate $(115 \mathrm{mg} / \mathrm{L}$ and $336 \mathrm{mg} / \mathrm{L})$ with low amount of magnesium $(2.5 \mathrm{mg} / \mathrm{L})$ or sulfate (6.3 mg/L) (Peyraube et al., 2012). Manual measurements of pH, electrical conductivity, and temperature were carried out from 2007 to 2010 with a Hach Lange WTW 340i for conductivity (tetracon 325-20 probe) and WTW 330i for $\mathrm{pH}$ (Sentix 41 probe) along with field measurement of bicarbonate (Hach Lange alkalinity test kit model AL-DT). Sample was taken in two $60 \mathrm{ml}$ HDPE bottles: one bottle was dedicated for anions and the other bottle was used for cations (with nitric acid). Major ion analysis was performed using Dionex ICS 1500 liquid chromatography. Field measurements and sampling started in 2007.

For Lascaux site, the cave is monitored since the 1960's considering parameters such as air temperature and $\mathrm{CO}_{2}$ proportion. Water quality is monitored since the 1990's. In Lascaux site, water is sampled in a spring located in an airlock (SAS1), giving access to the cave of Lascaux. The water of SAS1 spring comes from the epikarst compartment in Coniacian (86.3 to 89.8 Million years) limestone. Water from the roof is collected from gutters and let it accumulated in the device for measurement. The spring is not perennial and the discharge is low, $70 \mathrm{~m}^{3} /$ day. Calcium is $145 \mathrm{mg} / \mathrm{L}$ on the average, bicarbonate is $416 \mathrm{mg} / \mathrm{L}$. In the absence of dolomite or gypsum, magnesium and sulfate are low, $1.5 \mathrm{mg} / \mathrm{L}$ and $5.5 \mathrm{mg} / \mathrm{L}$, respectively (Houillon 2016). Bicarbonate and major ions were obtained using the same materials and methods as Cussac site.

\section{Proposed Method}

\subsection{Analytical Expressions}


The aim of the article is to provide a tool which is a field abacus for calculating SIc. This abacus can be developed from spreadsheet software. Table 3 proposes an organization of the spreadsheet in order to calculate and build the abacus. Equations associated with the calculation are also presented. Temperature (column 2), conductivity (column 3), $\mathrm{pH}$ (column 4), and bicarbonate concentration (column 5) can be measured on field. Calcium (column 6) and other major ion concentrations can be measured in the laboratory (columns 7 to 12 for sodium, magnesium, potassium, chloride, nitrate and sulfate; other ions can be added if necessary).

From the concentrations of the major ions, Ionic Strength (IS) is calculated in column 13 with Equation 1 ( $\mathrm{Ci}$ is the molarity and $\mathrm{zi}$ is the valence).

Equation $1:$ Ionic Stregh $=\frac{1}{2} * \sum \mathbf{C}_{\mathbf{i}} * \mathbf{z}_{\mathbf{i}}^{2}$

Once Ionic Strength is calculated, activity coefficient $\gamma \mathrm{i}$ can be calculated using Equation 2 presented by Truesdell and Jones (1973). It is a modified version of the Debye-Hückel equation (1923). $z_{i}$, is the valence of the considered ion, $a_{i}$ and $b_{i}$ ion-specific parameters and $\mathrm{T}$ the temperature is in Kelvin (column 2). Values of $a_{i}$ and $b_{i}$ are presented by Appelo and Postma (2005). Only the activity coefficient of bicarbonate and calcium are needed and calculated in columns 14 and 15.

Equation $2: \gamma \mathbf{i}=10^{\left(\mathbf{b}_{\mathbf{i}} * \mathbf{I S}+\left(\frac{(-1820000 *(80.3 * T)) * \mathrm{z}_{\mathbf{i}}^{2} * \sqrt{I S}}{1+\left(50.3 *(30.3 * \mathbf{T}) * \mathbf{a}_{\mathbf{i}} * \sqrt{\mathrm{IS}}\right.}\right)\right)}$

In this article, $\left[\mathrm{HCO}_{3}{ }^{-}\right]$refers to the activity of bicarbonate, $\mathrm{HCO}_{3}{ }^{-}$refers to the mass concentration of bicarbonate in $\mathrm{mg} / \mathrm{L}$, and $\left\{\mathrm{HCO}_{3}{ }^{-}\right\}$refers to the molarity of bicarbonate in mol/L. Equation 3 presents the relationship among these parameters: activity, molarity and mass concentration for the bicarbonate (as an example). 
Equation 3: $\left[\mathrm{HCO}_{3}^{-}\right]=\left\{\mathrm{HCO}_{3}^{-}\right\} * \boldsymbol{\gamma}_{\mathrm{HCO}_{3}}=\mathrm{HCO}_{3}^{-} * \frac{\gamma_{\mathrm{HCO}_{3}}}{\mathrm{M}_{\mathrm{HCO}_{3}}}$

With the concentrations (columns 5 and 6) and activity coefficients (columns 14 and 15) of bicarbonate and calcium, activities of these two ions can be calculated using Equation 3 in columns 16 and 17.

It should be noted that, on the average, for the presented data set, calcium and bicarbonate represent $95 \%$ of the ionic strength, the rest of the other major ions represent $5 \%$. It means that if the calculation considered calcium and bicarbonate only, it can correspond to an underestimation of IS. This underestimation would then lead to an estimation of about $1.4 \%$ higher for $\gamma_{\mathrm{Ca}}$ and $0.4 \%$ higher for $\gamma_{\mathrm{HCO} 3}$. The difference can be negligible, however, in this section, the real IS calculated with all the major ions is used.

The used equilibrium constants $K_{0} K_{1} K_{2}$ and Ks were presented by Langelier (1936) and Bakalowicz (1979) and summarized in a previous article (Peyraube et al., 2012). $\mathrm{K}_{0}$ is the Henry gas solubility constant, $\mathrm{K}_{1}$ and $\mathrm{K}_{2}$ are the first and second equilibrium constants, respectively, $\mathrm{K}_{\mathrm{s}}$ is the calcite solubility constant. All these constants depend on temperature (Plummer and Busenberg 1982). The constants for a given temperature (column 2) are calculated in columns 18 to 21 .

Equilibrium equations for calcite saturation are known and presented by Ford and Willams (2007) and Appelo and Postma (2005). The aim here is to modify the analytical expression of equilibrium equations to obtain an expression of SIc from parameters that can be easily estimated or measured on field. Equations are derived from the analytical expressions of equilibrium constants $\left(\mathrm{K}_{0}, \mathrm{~K}_{1}, \mathrm{~K}_{2}\right.$ and $\left.\mathrm{K}_{\mathrm{S}}\right)$ as presented by Peyraube et al. (2014). SIc is the logarithmic expression of the multiplication of calcite solubility products over the reaction constant (Equation 4). In this equation, the logarithm of carbonate activity can be expressed as a function of $\mathrm{K}_{2}$, bicarbonate activity and $\mathrm{pH}$ (or $-\log \left[\mathrm{H}^{+}\right]$in Equation 5). 
Then a new expression of SIc is obtained (Equation 6). This expression is used in column 22. Also, the equilibrium $\mathrm{CO}_{2}$ partial pressure $\mathrm{Pco}_{2}$ eq can be calculated in column 23 from $\mathrm{pH}$, bicarbonate activity, and constants $\mathrm{K}_{1}$ and $\mathrm{K}_{0}$ (Equation 7).

$$
\begin{aligned}
& \text { Equation } 4: \text { SIc }=\log \left[\mathrm{CO}_{3}^{2-}\right]+\log \left[\mathrm{Ca}^{2+}\right]+\log \left(\frac{1}{\mathrm{Ks}}\right) \\
& \text { Equation } 5: \log \left[\mathrm{CO}_{3}^{2-}\right]=-\log \left[\mathrm{H}^{+}\right]+\log \left[\mathrm{HCO}_{3}^{-}\right]+\log \left(\mathrm{K}_{2}\right) \\
& \text { Equation } 6: \mathrm{SIc}=\mathrm{pH}_{\text {measured }}+\log \left[\mathrm{HCO}_{3}^{-}\right]+\log \left[\mathrm{Ca}^{2+}\right]+\log \left(\frac{\mathrm{K}_{2}}{\mathrm{Ks}}\right) \\
& \text { Equation } 7:-\log \left(\mathrm{PCO}_{2} \text { eq }\right)=+\mathrm{pH}_{\text {measured }}-\log \left[\mathrm{HCO}_{3}^{-}\right]-\log \left(\frac{1}{\mathrm{~K}_{0} * \mathrm{~K}_{1}}\right)
\end{aligned}
$$

In addition, there is a possibility to express calcium activity as a function of bicarbonate activity. In karst water, molarity of calcium and bicarbonate are often considered proportional (Equation 8). This can be stated if the concentrations of magnesium (from $\mathrm{MgCO}_{3}$ ) and sulfate (from $\mathrm{CaSO}_{4}$ ) are low. In these conditions, the activity of calcium can be calculated from the activity of bicarbonate using: Equation 9 (with the definition of activity in Equation 2).

Equation $8:\left\{\mathrm{Ca}^{2+}\right\}=\left\{\mathrm{HCO}_{3}^{-}\right\} * \frac{1}{2}$

Equation $9: \frac{\left[\mathrm{Ca}^{2+}\right]}{\gamma_{\mathrm{Ca}}}=\frac{\left[\mathrm{HCO}_{3}^{-}\right]}{\gamma_{\mathrm{HCO}_{3}}} * \frac{1}{2}$

Figure 2.A presents the correlation between calcium and bicarbonate molarities for 1152 values of the data set. The linear regression (orange dash line) gives a slope of 0.52 , which is close to the theoretical proportional factor of 0.5 in Equation 8 (in Figure 2.A presented in the red straight line defined by this equation). This theoretical red line is computed with Equation 8. The difference between calculated and measured calcium molarity is presented in Figure 2.B. The difference falls in the range of $-9 \%$ to $+3 \%$ in three over four cases. Calculation overestimates the calcium molarity in most of the cases. For calcium 
molarity estimation, the median of the difference is $-3.0 \%$ and the median on absolute values of the difference is $4.3 \%$. Then, it appears acceptable to use the estimated values of calcium in the SIc calculations.

\subsection{Building the Abacus}

Figure 3 presents the tool for SIc and $\mathrm{Pco}_{2} \mathrm{eq}$ estimation named the SIc-Abacus. This abacus can be used in considering these conditions: 1) water comes from a karstic spring in a limestone context with the absence of dolomite; 2) water acidity comes from dissolved $\mathrm{CO}_{2}$; 3) calcium and bicarbonate are the main contributors of Ionic Strength, with low amount of magnesium, sulfate, chloride or sodium; 4) calcium and bicarbonate are proportional; and 5) bicarbonate can be calculated from electrical conductivity. In theory, the calculations of equilibrium constants $\left(\left(\mathrm{K}_{0}, \mathrm{~K}_{1}, \mathrm{~K}_{2}\right.\right.$ and $\left.\mathrm{K}_{\mathrm{S}}\right)$ can be applied for a temperature ranging from $0^{\circ} \mathrm{C}$ to $90^{\circ} \mathrm{C}$ (Plummer and Busenberg 1982).

The SIc-Abacus is based on the $\mathrm{SIc}=f\left(-\log \left(\mathrm{PcO}_{2} \mathrm{eq}\right)\right)$ reference frame. SIc from Equation 6 corresponds to the $\mathrm{Y}$ axis and $-\log \left(\mathrm{Pco}_{2} \mathrm{eq}\right)$ from Equation 7 corresponds to the $\mathrm{X}$ axis. The SIc-Abacus presented in Figure 3 is made for a temperature of $13^{\circ} \mathrm{C}$, close to the average temperature on the ground in Southwest of France. It is important to note that the SIc-Abacus can be calculated for any temperature. For a better approximation, one should use a SIc-Abacus built according to the expected water temperature. Therefore, it is suggested to go on field with a booklet of SIc-Abacus covering a large range of water temperature. Also, one can bring a smartphone with spreadsheet software installed and run the SIc-Abacus on field (as long as the battery functions).

In the SIc-Abacus, a constant bicarbonate concentration is represented by an oblique straight line from bottom-left to up-right. Basically, only two points are needed to construct one line. Then, in the spreadsheet software, a value of bicarbonate is chosen and calcium is 
estimated using Equation 9. Calculation of SIc and $-\log \left(\mathrm{PcO}_{2} \mathrm{eq}\right)$ are made for extreme arbitrary $\mathrm{pH}$ values of 5 and 10 . These extreme values are chosen to ensure that the line is defined for all the range of the abacus. In addition, on the SIc-Abacus, a constant $\mathrm{pH}$ is represented by a slightly curved line going from bottom-right to up-left. Then, in the spreadsheet software, one should calculate SIc for a given value of $\mathrm{pH}$ and several values of bicarbonate. For example, $\mathrm{pH}$ line 7.3 is built with 31 values of bicarbonate concentrations from $36 \mathrm{mg} / \mathrm{L}$ to $1667 \mathrm{mg} / \mathrm{L}$ (and corresponding calcium concentration), leading to a SIc ranging from -1.5 to +1.5 . Graduations of $\mathrm{pH}$ and bicarbonate were built to have a $\mathrm{pH}$ scale of 0.1 and a bicarbonate scale of $50 \mathrm{mg} / \mathrm{L}$.

Estimated values of SIc and $\mathrm{Pco}_{2}$ eq from the SIc-Abacus, however, should not be considered as a substitute from a classical calculation if SIc is needed with high accuracy. This abacus can be used as a tool to get an idea of the water chemistry. For example, it can be used for extensive mapping of SIc in an area to have a glance of the regional behavior of water. It can also help in deciding, directly on field, if further sampling and measurements can help in attaining the objectives or not. It gives fast result on the spot rather than collecting and analyzing then deciding after if the potential site is interesting or not (according to the aim of the study). Finally, it can also be applied for obtaining a continuous estimation of SIc, from continuous measurements of electrical conductivity and $\mathrm{pH}$.

\subsection{Precision of Measured Data in SIc-Abacus}

According to Equation 6, four parameters should be taken into account to estimate the accuracy of SIc: temperature, $\mathrm{pH}$, bicarbonate and calcium concentrations. Proposing a direct calculation of the uncertainty of SIc is out of range of this article. Uncertainty on $\mathrm{HCO}_{3}{ }^{-}$has an influence on $\log \left[\mathrm{HCO}_{3}{ }^{-}\right]$and on the Ionic Strength. The latter, in turn, has an influence on $\gamma_{\mathrm{Ca}}$ and $\gamma_{\mathrm{HCO} 3}$ which, in turn has an influence on $\log \left[\mathrm{HCO}_{3}{ }^{-}\right]$. For this reason, we preferred to 
tackle the range of possible SIc values rather than uncertainty. The calculation of the range of possible SIc values does not rely on a mathematical calculation of the uncertainty; it is a comparison of the possible values of SIc according to the range of values of the measured parameters.

In general, on field and laboratory, parameters are measured with uncertainty: temperature is $\pm 0.1^{\circ} \mathrm{C}, \mathrm{pH}$ is $\pm 0.05 \mathrm{pH}$ units (with Hach Lange WTW 3430 multimeter), bicarbonate is $\pm 2.5 \mathrm{mg} / \mathrm{L}$ (with Hach lange field test kit) and calcium is $\pm 2 \mathrm{mg} / \mathrm{L}$ (with liquid chromatography). Then, each measured parameter is associated with a possible maximum value, a measured value and a possible minimum value according to the uncertainty of the measurement.

Temperature is used to calculate the equilibrium constants $\left(\mathrm{K}_{0}, \mathrm{~K}_{1}, \mathrm{~K}_{2}\right.$, and $\left.\mathrm{K}_{\mathrm{S}}\right)$. The uncertainty on temperature has an effect on the value of $\mathrm{K}_{0}, \mathrm{~K}_{1}, \mathrm{~K}_{2}$, and $\mathrm{K}_{\mathrm{S}}$, and, finally, on SIc. We consider the "measured-SIc" as the result of the calculation using the measured $\mathrm{pH}$, bicarbonate and calcium concentrations. This "measured-SIc" is taken as a reference then compared to the result of the calculation involving: 1) the measured temperature, 2) the measured temperature $+0.1^{\circ} \mathrm{C}$, and 3) the measured temperature $-0.1^{\circ} \mathrm{C}$. All calculations are made using Equation 6 and uncertainties on $\mathrm{pH}$; bicarbonate and calcium concentration are not taken into account at this point. The SIc will have a range of $\pm 0.0017 \mathrm{pH}$ unit around the value obtained with the given temperature. For this reason, uncertainty on temperature is no longer considered as a major contributor of SIc range of possible values. However, temperature still plays an important role in the calculation.

The next part is calculating SIc with each of the 27 combinations of maximum, measured or minimum value for each of the three other parameters: $\mathrm{pH}$, bicarbonate and calcium concentrations. Table 4 presents the example of the measurements done on the $6^{\text {th }}$ of February 2008 in Farfal spring (Cussac site). At this date, $\mathrm{pH}$ measured 7.26 $\pm 0.05 \mathrm{pH}$ units, 
bicarbonate concentration measured $350.8 \pm 2.5 \mathrm{mg} / \mathrm{L}$, and calcium concentration measured $114 \pm 2 \mathrm{mg} / \mathrm{L}$. This means that the value of $\mathrm{pH}$ can range from 7.21 to 7.31 , the value of bicarbonate concentration can range from 348.3 to $353.3 \mathrm{mg} / \mathrm{L}$, and the value of calcium concentration can range from 112 to $116 \mathrm{mg} / \mathrm{L}$. Table 4 shows the 27 calculated SIc values using Equation 6, taking into account the three possible values (minimum, actual measured, or maximum) of the three parameters $(\mathrm{pH}$, bicarbonate concentration, and calcium concentration). The table also gives the differences between the possible SIc and the "measured-SIc", i.e. calculated with the measured values and considered as a reference.

If the actual measured values of bicarbonate and calcium concentrations are used, the range of possible SIc values is directly the same as the uncertainty on $\mathrm{pH}$ as defined by Equation 6: $0.05 \mathrm{pH}$ units (in orange in Table 4). Considering the actual measured values of $\mathrm{pH}$ and calcium concentration, the range of possible SIc values is only $0.003 \mathrm{pH}$ unit (in blue in Table 4). Finally, if the actual measured values of $\mathrm{pH}$ and bicarbonate concentration are applied, the range of possible SIc values is $0.007 \mathrm{pH}$ units (in green in Table 4). For the three parameters, a maximum value will lead to an overestimation of SIc, compared to the reference (and in return, an underestimation for the minimum value). Then, as can be expected, higher difference is obtained when $\mathrm{pH}$, bicarbonate and calcium concentrations are taken with their maximum values. On the contrary, a minimum value in one of the parameters may compensate the effect of the maximum values on other parameters. This is especially true for bicarbonate and calcium concentrations for a given $\mathrm{pH}$. The accumulated effects of the uncertainty on measured $\mathrm{pH}$, bicarbonate and calcium concentrations give a value of SIc $\pm 0.060 \mathrm{pH}$ units. This accumulated effect corresponds to the difference between the SIc calculation using measured values and the average of the SIc calculations using the maximum or minimum values of $\mathrm{pH}$, bicarbonate and calcium concentrations. The accumulated effect decreases as the concentrations of bicarbonate and calcium increase. It varies from $\pm 0.118 \mathrm{pH}$ 
units for a bicarbonate concentration of $50 \mathrm{mg} / \mathrm{L}$, to $\pm 0.054 \mathrm{pH}$ units for a bicarbonate concentration of $750 \mathrm{mg} / \mathrm{L}$ (extremes values of the SIc-Abacus). This is as the uncertainty of $2.5 \mathrm{mg} / \mathrm{L}$ on bicarbonate has a bigger influence on small concentration than large concentration (the same can be stated for the uncertainty on calcium).

The 27 SIc values presented in Table 4 are displayed in Figure 4 in the $\mathrm{SIc}=f\left(-\log \left(\mathrm{PcO}_{2} \mathrm{eq}\right)\right)$ reference frame. In Figure 4, other values of Farfal spring are presented in order to compare the range of SIc and $\mathrm{Pco}_{2}$ eq of the Farfal spring from 2007 to 2009 and the range of the 27 possible values in one set of measurement ( $6^{\text {th }}$ of February 2008). These 27 values are separated in three groups: minimum $\mathrm{pH}$, actual measured $\mathrm{pH}$, and maximum $\mathrm{pH}$ groups. This underlines that the main uncertainty is coming from the $\mathrm{pH}$. It is coherent in the study of Sasowsky and Dalton (2005). Uncertainty on pH value would lead to a shift of the position of the measured value alongside the straight line model of the Farfal spring (line in orange in Figure 4) as defined by Peyraube et al. (2012). On the contrary, uncertainty on bicarbonate and calcium concentration values has a little impact on the positioning of the point (x,y coordinates) on the graph.

In Figure 4, the red cross presents the possible position area for the measurement of SIc on the $6^{\text {th }}$ of February 2008 (presented by Peyraube et al., 2012). However, the presentation given by the red cross is not fit for the interpretation of the positioning of the point on the graph. This is as it projects directly the ranges of $-\log \left(\mathrm{Pco}_{2} \mathrm{eq}\right)$ and SIc on the $\mathrm{X}$ abscise and Y-Abcisse. Considering the 27 possible values of SIc presented in Table 4, the possible position area on the graph should be expected in the green area. The size of the green area depends on the field and laboratory measurements. Furthermore, the range of SIc possible values will be the same even if the calculation is performed with spreadsheet software, PHREEQC, WATEQ4F or WATSPEC. 


\section{Results and Discussion}

\subsection{Estimations of Field Values}

SIc-Abacus can be used directly on field with measured values of $\mathrm{pH}$ and bicarbonate (the measured temperature helps to choose the corresponding SIc-Abacus in the booklet). However, the measurement of bicarbonate can give limits or inconveniences: for example, the alkalinity test kit could be bulky and could represent as an additional weight. Also, it needs enough reaction powder and acid with functional glassware. Moreover, the measurement of bicarbonate should be done in a limited time after sampling. In a water sampling bottle, bicarbonate concentration can vary after some hours. This is due to the difference between the $\mathrm{CO}_{2}$ concentration in the atmosphere and the $\mathrm{CO}_{2}$ concentration in equilibrium with water. The difference leads the water to degas $\mathrm{CO}_{2}$ and, subsequently, precipitates calcium carbonate. Therefore, as long as only an estimation of bicarbonate is a concern, SIc-Abacus is helpful as it can provide an immediate assessment of a spring.

In karst water, mainly dominated by calcium and bicarbonate ions, there is a known relationship in estimating bicarbonate and electrical conductivity. The estimation of bicarbonate concentration from electrical conductivity is already applied in some studies (Liu et al., 2007; Lambàn et al., 2015; Zeng et al., 2016). The relationship among these parameters is described by Groves and Meiman (2005) and Krawczyk and Ford (2006).

Figure 5.A presents the data from 1152 field measurements of bicarbonate concentration (in $\mathrm{mg} / \mathrm{L}$ ) and electrical conductivity measured on field (in $\mu \mathrm{S} / \mathrm{cm}$ ) in the different springs. Conductivity was measured for various temperatures (according to the site and the time of sampling), yet the data set presents the corrected conductivity at $25^{\circ} \mathrm{C}$. Figure 5.A confirms the linear relationship between bicarbonate and electrical conductivity. The regression gives Equation 10 with a determination coefficient $\mathrm{R}^{2}=0.95$. 
Equation $10: \mathrm{HCO}_{3}^{-}=0.571 *$ Conductivity +17.194

The determination coefficient is high and the difference from $\mathrm{R}^{2}=1$ comes from the other major ions (magnesium, sodium, potassium, chloride, sulfate and nitrate) present in water in various proportions. Although these other major ions represent $5 \%$ only, on the average, of ionic strength (in the data set), their presence in water has an effect on electrical conductivity.

The difference between calculated and measured bicarbonate concentration is presented in Figure 5.B. The difference falls in the range of $-3 \%$ to $+3 \%$ in three over four cases. For bicarbonate concentration estimation, the median of the difference is $-0.04 \%$ and the median on absolute values of the difference is $1.8 \%$.

Then, on field, one can perform a conductivity measurement to estimate a bicarbonate concentration value and accept the assumption that calcium concentration is proportional to this estimated bicarbonate concentration. Using the SIc-Abacus, only a multimeter (for temperature, conductivity, and $\mathrm{pH}$ ) is needed to estimate SIc and $\mathrm{PCO}_{2}$ eq.

\subsection{Consequences of the Estimation on the Precision of the Acquired Values from}

\section{SIc-Abacus}

Using estimations of bicarbonate and calcium have consequences on the range of possible values of SIc. Calculation of SIc was performed using measured $\mathrm{pH}$ and estimated values of bicarbonate and calcium concentration using Equation 6. In this equation, calcium activity was calculated with Equation 3 from calcium molarity, calculated with Equation 8 from bicarbonate molarity. Bicarbonate activity was calculated with Equation 3 from bicarbonate concentration, calculated with Equation 10 from conductivity. 
In these conditions, estimation of the range of value makes use of the median of the difference between absolute values of calculated and measured bicarbonate (or calcium). This median is considered as an uncertainty on the estimation. Then, calcium molarity is obtained with an uncertainty of $\pm 4.3 \%$ and bicarbonate concentration is obtained with an uncertainty of $\pm 1.8 \%$. Also, conductivity is measured with an uncertainty of $\pm 5 \mu \mathrm{S} / \mathrm{cm}$.

Table 5 presents the consequences of the field estimations. It gives an example of the calculation of the range of SIc values using estimated parameters. The reference is taken from the measurements taken on the $6^{\text {th }}$ of February 2008, including measured conductivity of $584 \mu \mathrm{S} / \mathrm{cm}$ and measured $\mathrm{pH}$ of 7.26. The second line presents the effect of the estimations: bicarbonate concentration was calculated from measured electrical conductivity with Equation 10 giving $350.7 \mathrm{mg} / \mathrm{L}$ (close to the measured value of $350.8 \mathrm{mg} / \mathrm{L}$ ) and calcium concentration was calculated from calculated bicarbonate concentration with Equation 8 giving $115 \mathrm{mg} / \mathrm{L}$ (higher than the measured value of $114 \mathrm{mg} / \mathrm{L}$ ). Following lines in Table 5 shows the individuals effects of augmentation of electrical conductivity $(+5 \mu \mathrm{S} / \mathrm{cm})$, bicarbonate $(+1.8 \% \mathrm{mg} / \mathrm{L})$ and calcium $(+4.3 \% \mathrm{~mol} / \mathrm{L})$ concentrations. This means that measured conductivity plus $5 \mu \mathrm{S} / \mathrm{cm}$ is used to calculate bicarbonate concentration. This value is augmented of $1.8 \%$ before being used to calculate the calcium molarity. The value of calcium molarity is then augmented of $4.3 \%$. These values of bicarbonate and calcium concentrations and the measured $\mathrm{pH}$ were in turn used to calculate SIc and $\mathrm{PcO}_{2}$ eq. Accumulated effects of the augmentation led to an over estimation of the SIc of $0.040 \mathrm{pH}$ units. In return, accumulated effects of the diminution brought an under estimation of SIc of $0.034 \mathrm{pH}$ units. These values have to be withdrawn or added to the uncertainty on $\mathrm{pH}$ field measurement giving a range of value of +0.090 (i.e. +0.050 from $\mathrm{pH}$ plus +0.040 from other parameters) or -0.084 (i.e. -0.050 plus -0.034 from other parameters). Then, using field estimations, SIc range of value would be, on the average, equal to $\pm 0.087 \mathrm{pH}$ units. This range of value is 
inversely proportional to the bicarbonate and calcium concentrations. It is equal to $\pm 0.129 \mathrm{pH}$ units for a bicarbonate concentration of $50 \mathrm{mg} / \mathrm{L}$; for a bicarbonate concentration of 750 $\mathrm{mg} / \mathrm{L}$, it is equal to $\pm 0.082 \mathrm{pH}$ units.

In SIc-Abacus, the area corresponding to the range of possible SIc values is obtained by considering four extreme cases as a combination of the augmentation and diminution of $\mathrm{pH}$ in one hand and other parameter on the other hand (last four lines of the Table 5). Results are displayed in the SIc-Abacus on Figure 6.A. The violet area corresponds to the range of possible values using estimated parameters. For a better understanding, a zoom is provided in Figure 6.B. This area has a shape of a parallelogram and the small sides are not parallel to the $\mathrm{pH}$ scale. This is as, contrary to the building of the $\mathrm{pH}$ scale, calcium molarity is no longer considered equal to the half of bicarbonate molarity (Equation 8) when the $4.3 \%$ uncertainty is added (or withdrawn) to the calcium estimation. Figure 6 also presents the green area corresponding to the range of value of SIc when calculated with measured $\mathrm{pH}$, measured bicarbonate concentration and measured calcium concentration. This area has a parallelogram shape also, as calculation considers values of calcium and bicarbonate with their field and laboratory measurement uncertainties. The green parallelogram corresponds to the actual range of SIc values with measured $\mathrm{pH}$, bicarbonate and calcium concentration. The violet parallelogram is around three times larger than the green one. This range of uncertainty does not represent a problem for the purpose of SIc-Abacus: providing a field estimation of SIc. For example, the SIc-Abacus can help in deciding if it is appropriate to do a full sampling that includes field bicarbonate measurement and water sampling for calcium and other major ions measurement in the laboratory. Then, if the site is found worthy, one can perform a full sampling and a SIc calculation (and fall in the green rectangle). Note that whenever in doubt, full sampling is always a better option. 


\subsection{Evaluating SIc-Abacus: Application in Cussac and Lascaux Sites}

In this part we used the values from Cussac and Lascaux sites to compare the "measured-SIc" and the "estimated-SIc". "Measured-SIc" is calculated from measured pH, bicarbonate concentration and calcium concentration. "Estimated-SIc" is calculated from measured $\mathrm{pH}$ and estimated bicarbonate and calcium concentrations from measured electrical conductivity following the method of SIc-Abacus. In both cases, Equation 6 is used. Real values of SIc from measured $\mathrm{pH}$, bicarbonate and calcium concentrations are already available. This permits evaluating "estimated-SIc" that can be obtained using SIc-Abacus. Estimating SIc from calculated values of bicarbonate and calcium concentrations from electrical conductivity was already done (Liu et al., 2007). The aim here is to assess the consequences of the estimation in terms of range of values. The comparison relies on the values obtained in two springs: Farfal spring on Cussac site and SAS1 spring on Lascaux site.

For Cussac site, we focused on 59 SIc values obtained from $17^{\text {th }}$ of October 2007 to $16^{\text {th }}$ of December 2009. During this period, SIc was $0.050 \mathrm{pH}$ units on the average, varying from $-0.146 \mathrm{pH}$ units in autumn to $0.228 \mathrm{pH}$ units in winter. Variations of SIc are linked with degassing occurring in the unsaturated zone; processes were described in a previous article (Peyraube et al., 2012). SIc was calculated from $\mathrm{pH}$ values (from $6.91 \mathrm{pH}$ units to $7.3 \mathrm{pH}$ units, $7.10 \mathrm{pH}$ units on the average), bicarbonate concentration $(310 \mathrm{mg} / \mathrm{L}$ to $355 \mathrm{mg} / \mathrm{L}$, $336 \mathrm{mg} / \mathrm{L}$ on the average), calcium concentration $(110 \mathrm{mg} / \mathrm{L}$ to $120 \mathrm{mg} / \mathrm{L}, 115 \mathrm{mg} / \mathrm{L}$ on the average) and temperature $\left(12.0\right.$ to $13.0^{\circ} \mathrm{C}, 12.6^{\circ} \mathrm{C}$ on the average). Conductivity varied from $547 \mu \mathrm{S} / \mathrm{cm}$ to $607 \mu \mathrm{S} / \mathrm{cm}$ with an average of $582 \mu \mathrm{S} / \mathrm{cm}$.

In Lascaux site, the SAS1 spring is not perennial. Three cycles are considered: 20122013, 2013-2014, and 2014-2015. However, for the 2012-2013 cycle, the flow started in 2013 after the accumulated rain at the end of year 2012. From the 29 values, SIc varied from 0.048 $\mathrm{pH}$ units to $0.586 \mathrm{pH}$ units with an average of $0.371 \mathrm{pH}$ units. SIc was calculated from $\mathrm{pH}$ 
values (from $7.04 \mathrm{pH}$ units to $7.49 \mathrm{pH}$ units, $7.26 \mathrm{pH}$ units on the average), bicarbonate concentration ( $368 \mathrm{mg} / \mathrm{L}$ to $458 \mathrm{mg} / \mathrm{L}, 413 \mathrm{mg} / \mathrm{L}$ on the average), calcium concentration (121 $\mathrm{mg} / \mathrm{L}$ to $155 \mathrm{mg} / \mathrm{L}, 140 \mathrm{mg} / \mathrm{L}$ on the average) and temperature $\left(11.6\right.$ to $13.8^{\circ} \mathrm{C}, 12.5^{\circ} \mathrm{C}$ on the average). Conductivity varied from $625 \mu \mathrm{S} / \mathrm{cm}$ to $700 \mu \mathrm{S} / \mathrm{cm}$ with an average of $663 \mu \mathrm{S} / \mathrm{cm}$. Water flowing at SAS1 spring is always supersaturated with respect to calcite.

Figure 7 presents the values from Cussac site (Figure 7.A) and Lascaux site (Figure 7.B). Taking as a whole, in Figure 7 the blue line shows the variation of "measured-SIc", using Equation 6 on spreadsheet software (as described in Table 3). In light green, the "measured-SIc" range of values according to the uncertainties on the field measurement of $\mathrm{pH}$ and bicarbonate concentration, and laboratory measurement of calcium concentration is presented. In Figure 7, the orange line corresponds to the "estimated-SIc" using measured pH and electrical conductivity to estimate bicarbonate concentration (Equation 10) and calcium concentration (Equation 8). In light violet, the "estimated-SIc" range of values according to the method presented earlier is shown. Finally, when the ranges of "measured-SIc" and "estimated-SIc" are overlaying, the resulting color is a greyish green.

First, on both sites, the "estimated-SIc" appears close to the "measured-SIc". In Figure 7.A particularly, the cyclical variations of "measured-SIc" (in blue) are reproduced well by "estimated-SIc" (in orange). Second, the "estimated-SIc" range of values (in violet) is not far from the "measured-SIc" range of value (in green). In Cussac site, on the average, the "estimated-SIc" range of values is $45 \%$ bigger than the "measured-SIc" range of values. Similarly, in Lascaux site, the "estimated-SIc" range of values is $49 \%$ bigger than the "measured-SIc" range of values.

In Section 4.1, we showed that the "measured-SIc" range of values decreases as bicarbonate concentration increases. The same is observed for "estimated-SIc" range of values (Section 4.3). Figure 8 presents these variations. It shows that "estimated-SIc" range of 
values (in violet) is always bigger than "measured-SIc" range of values (in green). However, the proportion of "estimated-SIc" range of values, compared to "measured-SIc" range of values, increases as bicarbonate concentration increases (Figure 8). This proportion varies: for a bicarbonate concentration of $50 \mathrm{mg} / \mathrm{L}$, "estimated-SIc" range of values is $7 \%$ bigger than "measured-SIc" range of values; for a bicarbonate concentration of $750 \mathrm{mg} / \mathrm{L}$, "estimated-SIc" range of values is 51\% bigger than "measured-SIc" range of values.

The figure also presents the cases of Farfal spring on Cussac site and SAS1 spring on Lascaux site. For example in Cussac site, average bicarbonate concentration is $336 \mathrm{mg} / \mathrm{L}$, then "measured-SIc" range of values is \pm 0.060 , "estimated-SIc" range of values is \pm 0.087 and the proportion gives "estimated-SIc" range of values $45 \%$ higher than "measured-SIc" range of values. With Figure 8, it is possible to assess the consequences of the field estimation and to compare it to the consequences of a real measurement, including the effect of the sole $\mathrm{pH}$ uncertainty.

To show the accuracy of the estimation, Table 4 focuses on the average observed difference between "measured-SIc" and "estimated-SIc" without considering the range of value further. It presents the values of Cussac and Lascaux sites. For each site, only 10 examples are given (over a total of 88 ). The table also shows the difference between the "measured-SIc" and the "estimated-SIc". There is a goodness of fit between the "estimatedSIc-Abacus" and the "Measured-SIc-Abacus" with an $\mathrm{R}^{2}=0.85$ on the whole data set. The determination coefficient reaches $\mathrm{R}^{2}=0.91$ for Lascaux site and $\mathrm{R}^{2}=0.99$ for Cussac site. In addition, average values of this difference for Cussac site $(-0.015 \mathrm{pH}$ units, on the 59 values), Lascaux site (0.039 $\mathrm{pH}$ units, 29 values), and the whole data set $(0.077 \mathrm{pH}$ units, 1152 values $)$ are provided. In Cussac site, the overestimation of SIc resulted from the overestimation of bicarbonate concentration from electrical conductivity (Equation 10). On the other hand, in Lascaux site, the relationship between electrical conductivity and bicarbonate concentration 
has a tendency to underestimate bicarbonate concentration, and consequently, underestimate SIc.

However, the average difference remains low. This difference has to be compared to the accepted uncertainty of \pm 0.050 caused by the measurement of $\mathrm{pH}$. It means that the estimation of SIc, from SIc-Abacus, can represent an efficient and reliable method in obtaining SIc. It also implies less tedious and low cost procedure for an immediate SIc assessment of a site.

\subsection{Determining pH value, an Alternative Use of SIc-Abacus Equation: Application in}

\section{Lascaux Site}

In SAS1 spring in Lascaux site, continuous monitoring of temperature, conductivity, pH (Hach Lange WTW 3430 multimeter), and dissolved $\mathrm{CO}_{2}$ (Vaisala GMP251) was performed from the $22^{\text {nd }}$ of February 2015 to $31^{\text {st }}$ of March 2015 with a measurement done every 10 minutes. During this period, several measurements were performed manually to obtain the values of $\mathrm{pH}$, temperature and electrical conductivity (a second Hach Lange WTW 3430 multimeter was used). On the 5 measurements performed, the range of values obtained are as follows: $7.17 \mathrm{pH}$ units to $7.37 \mathrm{pH}$ units with an average of $7.26 \mathrm{pH}$ units for the $\mathrm{pH}$; $661 \mu \mathrm{S} / \mathrm{cm}$ to $668 \mu \mathrm{S} / \mathrm{cm}$ with an average of $675 \mu \mathrm{S} / \mathrm{cm}$ for the conductivity; from $1.51 \%$ to $2.23 \%$ with an average of $1.88 \%$ for the dissolved $\mathrm{CO}_{2}$; and $408 \mathrm{mg} / \mathrm{L}$ to $423 \mathrm{mg} / \mathrm{L}$ with an average of $413 \mathrm{mg} / \mathrm{L}$ for the bicarbonate.

To ensure a good quality measurement, the $\mathrm{pH}$ probe was recalibrated every two weeks, which means three times during the monitoring period. The need of calibration of the $\mathrm{pH}$ probe can be a limitation for $\mathrm{pH}$ monitoring. There, the conclusions attained from SIc-Abacus can help. 
Lascaux site as an example presents an alternative use of the equations and assumptions made for building the SIc-Abacus. The aim is to obtain $\mathrm{pH}$ value using parameters that are easier to measure than $\mathrm{pH}$ per se, i.e. electrical conductivity and dissolved $\mathrm{CO}_{2}$ (dissolved $\mathrm{CO}_{2}$ corresponds to $\left.\mathrm{Pco}_{2} \mathrm{eq}\right)$. Rewriting Equation 7, $\mathrm{pH}$ can be obtained using $\mathrm{Pco}_{2} \mathrm{eq}$ and bicarbonate concentration (Equation 11).

Equation $11: \mathrm{pH}_{\text {measured }}=-\log \left(\mathrm{Pco}_{2} \mathrm{eq}\right)+\log \left[\mathrm{HCO}_{3}^{-}\right]+\log \left(\frac{1}{\mathrm{~K}_{0} * \mathrm{~K}_{1}}\right)$

In this article, we showed that the uncertainty on bicarbonate concentration has a limited influence on the estimation of SIc, either the bicarbonate concentration is measured or estimated from electrical conductivity. Then, using an estimated value of bicarbonate concentration to calculate $\mathrm{pH}$ is possible, also with a limited influence. This is because the logarithm of bicarbonate concentration is used in the equations, whereas, $\mathrm{pH}$ or SIc are obtained directly (as pH and SIc are expressions already involving a logarithm).

Figure 9.A depicts the values of $\mathrm{Pco}_{2} \mathrm{eq}$ in SAS1 water (in green) and electrical conductivity (in violet) measured from the $22^{\text {nd }}$ of February 2015 to $31^{\text {st }}$ of March 2015. Bicarbonate concentration was measured on field (orange diamonds). As showed, there is a goodness of fit between measured and calculated bicarbonate concentration (orange line) from electrical conductivity. Figure 9.B presents the values of $\mathrm{pH}$ measured every 10 minutes in blue. The uncertainty on measured $\mathrm{pH}$ value $( \pm 0.05)$ is presented as grey error envelope. The pink line represents the $\mathrm{pH}$ estimated from Equation 11 using measured $\mathrm{Pco}_{2} \mathrm{eq}$, temperature, and estimated bicarbonate concentration from electrical conductivity measurement. The shape of the pink line (estimated $\mathrm{pH}$ ) corresponds to the reverse shape of the green line (measured $\left.\mathrm{PcO}_{2} \mathrm{eq}\right)$. This is as carbonic acid is the main provider of acid in Lascaux site. The estimated $\mathrm{pH}$ (in pink) seems close to the measured $\mathrm{pH}$ (in blue). Moreover, the pink line is within the range of the uncertainty on $\mathrm{pH}$ values (in grey). 
The range of values of the estimated $\mathrm{pH}$ was calculated using the same method as presented: extreme values of estimated $\mathrm{pH}$ were calculated considering the uncertainty on the parameters involved in the calculation. Conductivity is still measured with an uncertainty of $\pm 5 \mu \mathrm{S} / \mathrm{cm}$, bicarbonate concentration was estimated from conductivity with a median error of $\pm 1.8 \%$, and $\mathrm{Pco}_{2} \mathrm{eq}$ is measured with an uncertainty of $\pm 0.1 \%$. Doing so, the range of variation of estimated $\mathrm{pH}$ is so small that it cannot be presented in Figure 9. For example, on the $22^{\text {nd }}$ of February 2015 00:00, $\mathrm{pH}$ is estimated as $7.2079 \mathrm{pH}$ units, in the case where $\mathrm{Pco}_{2} \mathrm{eq}$ and conductivity have their measured values augmented, the estimated $\mathrm{pH}$ diminished by $0.0088 \mathrm{pH}$ units $\left(0.0112 \mathrm{pH}\right.$ units on the average on the period). In the case where $\mathrm{PcO}_{2} \mathrm{eq}$ and conductivity diminished, the calculated $\mathrm{pH}$ augmented by $0.0096 \mathrm{pH}$ units $(0.0122 \mathrm{pH}$ units on the average of the period).

Finally, the combined use of $\mathrm{Pco}_{2} \mathrm{eq}$ and conductivity (as a proxy for bicarbonate concentration) represents an alternative method of obtaining $\mathrm{pH}$. This is useful specifically in a water point in carbonated limestone environment that are hard to access. The specific interest is to leave the dissolved $\mathrm{CO}_{2}$ and electrical conductivity sensor in the spring for a long time. This would spare a regular recalibration of the $\mathrm{pH}$ probe. However, in doing so, the good relationship between bicarbonate concentration and electrical conductivity should be assessed first.

\section{Conclusion}

The main objective of this research is to propose an in-situ tool to estimate the Saturation Index with respect to calcite (SIc) and equilibrium $\mathrm{CO}_{2}$ partial pressure $\left(\mathrm{Pco}_{2} \mathrm{eq}\right)$ called SIc-Abacus. The abacus based on the $\mathrm{SIc}=f\left(-\log \left(\mathrm{PcO}_{2} \mathrm{eq}\right)\right.$ reference frame can be printed and used on field (in-situ) taking into account electrical conductivity, temperature and 
$\mathrm{pH}$ as parameters. It can serve its function in making decisions that involves carbonate karst concerns (e.g. if a site will be useful in their research studies or not).

The abacus relies on two assumptions that limit its use in the context of limestone, without low amounts of magnesium and sulfate. First, the calcium concentration is proportional to bicarbonate concentration and second, the bicarbonate concentration can be calculated from electrical conductivity. The estimation of SIc with SIc-Abacus is less precise than a classical calculation of SIc involving measurements of bicarbonate and calcium concentrations. That is why precision in using this abacus was evaluated. Considering the uncertainties on the values of $\mathrm{pH}$, electrical conductivity, bicarbonate and calcium concentrations, the range of values of estimated SIc is $+/-0.087 \mathrm{pH}$ units and the range of possible values of SIc calculated with measured parameters is $+/-0.054 \mathrm{pH}$ units (example for a bicarbonate concentration close to $350 \mathrm{mg} / \mathrm{L}$ ).

The method is assessed on Lascaux and Cussac sites (Southwest France). SIc calculated with estimated parameters (using SIc-Abacus equations), are close to the SIc calculated with measured parameters. The estimation of SIc follows the cyclical variations of SIc. The difference is -0.015 on Cussac site and 0.039 on Lascux site. We showed that, for each sample, the range of values of the estimated SIc is only 45 to $49 \%$ bigger than the range of value of SIc induced by field measurements.

It is important to keep in mind that the estimation of SIc does not replace the real calculation of SIc if precision is needed. Nevertheless, it can help in giving approximate assessments of the SIc of a spring or other carbonate systems instantaneously, directly on field. It can be used to provide a continuous monitoring of SIc based on the values of conductivity and $\mathrm{pH}$ (or $\mathrm{PCO}_{2} \mathrm{eq}$ ). Also, the presentation of the consequences (considering the uncertainties) of the field estimation helps in attesting the reliability of this approach. 


\section{Acknowledgment}

We thank the DRAC Aquitaine for their financial and technical support in monitoring Cussac and Lascaux sites. We thank also the SNO KARST for their input.

\section{References}

Abongwa P.T., Atekwana E.A., 2015. Controls on the chemical and isotopic composition of carbonate springs during evolution to saturation with respect to calcite. Chemical Geology. 404, 136-149

Appelo C.A.J., Postma D., 2005. Geochemistry, groundwater and pollution, edition A.A. balkema, 2nd edition, ISBN: 04-1536-421-3.

Bakalowicz M., 1979. Contribution de la géochimie des eaux à la connaissance de l'aquifère karstique et de la karstification, thèse, université de Paris VI, , 269p.

Binet S., Mudry J., Bertrand C., Guglielmi Y., Cova R., 2005. Estimation of quantitative descriptors of mediterranean karst behavior. multiparametric study and local validation on the Siou-Blanc massif (Toulon, France). Hydrogeology journal 14, 952-960.

Binet S., Probst J.-L., Batiot-Guilhe C., Seidel J.-L., Emblanch C., Peyraube N., Mangin A., Bakalowicz M., Probst A., 2017. Impact of atmospheric pollution inputs and climate change on dissolved inorganic carbon fluxes in karst aquifers: evidences from a 36 years past monitoring of karstic watersheds. EGU General Assembly Conference Abstracts.

Bono P., Dreybrodt W., Ercole S., Percopo C., Vosbeck K., 2001. Inorganic calcite precipitation in Tartare karstic spring (Lazio, central Italy): field measurements and theoretical prediction on depositional rates. Environmental Geology. 41, 305-313 
Caboi R., Cidu R ., Fanfani L., Zuddas P., Zanzari A.R., 1993. Geochemistry of the high-Pco 2 waters in Logudoro, Sardinia, Italy. Applied Geochemistry. 8, 153-160

Cantonati M., Segadelli S., Ogata K., Tran H., Sanders D., Gerecke R.,Rott E., Filippini M., Gargini A., Celico F., 2016. A global review on ambient Limestone-Precipitating Springs (LPS): Hydrogeological setting, ecology, and conservation. Science of the total environment. 568, 624-637

Cooper R.J., Wadhama J.L., Tranter M., Hodgkins R., Peters N.E., 2002. Groundwater hydrochemistry in the active layer of the proglacial zone, Finsterwalderbreen, Svalbard. Journal of Hydrology. 269, 208-223

Charlier J-B., Bertrand C., Mudry J., 2012. Conceptual hydrogeological model of flow and transport of dissolved organic carbon in small Jura karst system. Journal of Hydrology 460, 52-64

Debye P. Hückel E., 1923. The theory of electrolytes. I. Lowering of freezing point and related phenomena. Physikalische Zeitschrift 24, 185-206

Denimal S., Bertrand C., Steinmann M., Carry N., 2017. Comparison of Flow Processes in Drains and Low Permeability Volumes of a Karst System in the French Jura Mountains: High-Resolution Hydrochemical Characterization During a Flood Event. Advances in Karst Science, doi.org/10.1007/978-3-319-45465-8_29

Dreybrodt W., Buhmann D., Michaelis J., Usdowski E., 1992. Geochemically controlled calcite precipitation by $\mathrm{CO}_{2}$ outgassing: Field measurements of precipitation rates in comparison to theoretical predictions. Chemical Geology. 97, 285-294

Dreybrodt W., Scholz D., 2011. Climatic dependence of stable carbon and oxygen isotope signals recorded in speleothems: From soil water to speleothem calcite. Geochimica et Cosmochimica Acta. 75, 734-752 
Edmunds W.M., Cook J.M., Darling W.G., Kinniburgh, Miles D.L., Bath A.H., Morgan-Jones M., Andrews J.N., 1987. Baseline geochemical conditions in the Chalk aquifer, Berkshire, U.K.: a basis for groundwater quality management. Applied Geochemistry. 2, 251-274

Ford D., Williams P., 2007. Karst hydrogeology and geomorphology, edition Wiley, 7th edition, ISBN: 978-0-470-84997-2, 562p.

Groleau A., Sarazin G., Vincon-Leite B., Tassin B., Quiblier-Lloberas C., 2000. Tracing calcite precipitation with specific conductance in a hard water alpine lake (lake bourget). Water Research. 34, 4151-4160

Groves C., Meiman J., 2005. Weathering, geomorphic work, and karst landscape evolution in the Cave City groundwater basin, Mammoth Cave, Kentucky. Geomorphology. 67, 115-126.

Hattanji T., Ueda M., Song W., Ishii N., Hayakawa Y.S., Takaya Y., Matsukura Y., 2014. Field and laboratory experiments on high dissolution rates of limestone in stream flow. Geomorphology. 2014, 485-492

Herman J., Lorah M., 1987. $\mathrm{CO}_{2}$ Outgassing and calcite precipitation in falling spring creek, Virginia, USA. Chemical geology. 62, 251-262

Hess J.W., White W.B., 1993. Groundwater geochemistry of the carbonate karst aquifer, southcentral Kentucky, U.S.A. Applied Geochemistry. 8, 189-204

Kanduč T., Mori N., Kocman D., Stibilj V., Grassa F. 2012. Hydrogeochemistry of Alpine springs from North Slovenia: Insights from stable isotopes, Chemical geology 300-301, 40-54.

Keppel M.N., Post V.E.A., Love A.J., Clarke J.D.A., Werner A.D., 2012. Influences on the carbonate hydrochemistry of mound spring environments, Lake Eyre South region, South Australia. Chemical Geology. 296, 50-65 
Krawczyk W.E., Ford D.C., 2006. Correlating specific conductivity with total hardness in limestone and dolomite karst waters. Earth Surface Processes and Landforms. 31, $221-234$

Langelier W.F., 1936, the analytical control of anti-corrosion water treatment. Journal of American waterworks association. 28, 1500-1521

Lambán L.J., Jódar J., Custodio E., Soler A., Sapriza G., Soto R., 2015. Isotopic and hydrogeochemical characterization of high-altitude karst aquifers in complex geological settings. The Ordesa and Monte Perdido National Park (Northern Spain) case study. Science of the Total Environment. 507, 466-479

Lastennet R., Mudry J., 1997. Role of karstification and rainfall in the behavior of a heterogeneous karst system. Environmental Geology. 32, 14-123.

Liu Z., Li Q., Sun H., Wang J., 2007. Seasonal, diurnal and storm-scale hydrochemical variations of typical epikarst springs in subtropical karst areas of SW China: Soil $\mathrm{CO}_{2}$ and dilution effects. Journal of Hydrology. 337, 207-223

McDonald J., Drysdale R., Hill D., Chisari R., Wong H., 2007. The hydrochemical response of cave drip waters to sub-annual and inter-annual climate variability, Wombeyan Caves, SE Australia. Chemical Geology. 244, 605-623

Minvielle S., Lastennet R., Denis A., Peyraube N., 2015. Characterization of karst systems using SIc- $\mathrm{PCO}_{2}$ method coupled with PCA and frequency distribution analysis. Application to karst systems in the Vaucluse County (Southeastern France). Environmental Earth Sciences. 74, 7593-7604

Panda B., Chidambaram S., Thilagavathi R., Thivya C., Ganesh N., Devraj N., 2017. Geochemical signatures of groundwater along mountain front and riparian zone of Courtallam, Tamilnadu. Groundwater for Sustainable Development. https://doi.org/10.1016/j.gsd.2017.10.003 
Pentecost A., 1992. Carbonate chemistry of surface waters in a temperate karst region: the southern Yorkshire Dales, UK. Journal of Hydrology. 139, 211-232

Peyraube N., Lastennet R., Denis A., 2012. Geochemical evolution of groundwater in the unsaturated zone of a karstic massif, using the $\mathrm{Pco}_{2}$-SIc relationship. Journal of Hydrology. 431, 13-24

Peyraube N., Lastennet R., Denis A., Malaurent P., 2013. Estimation of epikarst air $\mathrm{Pco}_{2}$ using measurements of water $\mathrm{d}_{13} \mathrm{C}_{\mathrm{TDIC}}$ and cave air $\mathrm{Pco}_{2}$ and $\mathrm{d}^{13} \mathrm{CcO}_{2}$. (Cussac Cave and Lascaux Cave sites, France). Geochimica et Cosmochimica Acta. 118, 1-17

Peyraube N., Lastennet R., Denis A., Villanueva J.D., 2014. Interpreting $\mathrm{CO}_{2}$-SIc relationship to estimate $\mathrm{CO}_{2}$ baseline in limestone. Environmental Earth Sciences. 72, 4207-4215

Plummer L.N., Busenberg E., 1982. The solubility of calcite, argonite and waterite in $\mathrm{CO}_{2-}$ $\mathrm{H}_{2} \mathrm{O}$ solutions between 0 and $90^{\circ} \mathrm{C}$, and evaluation of the aqueous model of the system $\mathrm{CaCO}_{3}-\mathrm{CO}_{2}-\mathrm{H}_{2} \mathrm{O}$. Geochimica et Cosmochimica Acta. 46, 1011-1040.

Pu J., Wang A., Shen L., Yin J., Yuan D., Zhao H., 2015. Factors controlling the growth rate, carbon and oxygen isotope variation in modern calcite precipitation in a subtropical cave, Southwest China. Journal of Arabian Earth Sciences. http://dx.doi.org/10.1016/j.jseaes.2015.12.010

Sasowsky I.D., Dalton C.T., 2005. Measurement of pH for field studies in karst areas. Journal of Cave and Karst Studies. 67, 2, 127-132.

Truesdell A.H., Jones B.F., 1973. Wateq, a computer program for calculating chemical equilibria of natural water, US geological survey.

Yan H., Schmitt A.D., Liu Z., Gangloff S., Sun H., Chen J., Chabaux F., 2016. Calcium isotopic fractionation during travertine deposition under different hydrodynamic 
conditions: Examples from Baishuitai (Yunnan, SW China). Chemical Geology. 426, $60-70$

Yang R., Liu Z., Zeng C., Zhao M., 2012. Response of epikarst hydrochemical changes to soil $\mathrm{CO}_{2}$ and weather conditions at Chenqi, Puding, SW China. Journal of Hydrology. $468,151-158$

Zeng C., Liu Z., Zhao M., Yang R., 2016. Hydrologically-driven variations in the karst-related carbon sink fluxes: Insights from high-resolution monitoring of three karst catchments in Southwest China. Journal of Hydrology. 533, 74-90 


\section{Figure and Table Captions}

Figure 1 : Schematic maps of Lascaux (a) and Cussac (b) sites (modified from Peyraube et al. 2013)

Figure 2 : A. Calcium molarity as a function of bicarbonate molarity, red line is the theoretical relationship, dashed orange line is the statistical relationship based on the $\mathbf{1 1 5 2}$ measured data points; B. Difference between calculated and measured calcium molarity, median error on absolute value is provided.

Figure 3: SIc-Abacus, built for a temperature of $13^{\circ} \mathrm{C}$, in the $\mathrm{SIc}=\mathrm{f}\left(\log \left(\mathrm{Pco}_{2} \mathrm{eq}\right)\right)$ reference frame; field scale for $\mathrm{pH}$ and bicarbonate are displayed in blue and red, respectively; In green, on $\mathrm{X}$-abscise, $\mathrm{Pco}_{2}$ eq is expressed in percent, then $\mathrm{Pco}_{2} \mathrm{eq}=1 \%$ leading to $-\log (0.01)=2$

Figure 4: Farfal spring (Cussac site) data in the $S I c=f\left(\log \left(\mathrm{Pco}_{2} \mathrm{eq}\right)\right)$ reference frame (orange diamonds); the red cross is a misleading shape of the SIc range of possible value; green parallelogram is the real shape of the SIc range of possible value presented in Table 4.

Figure 5: A. Bicarbonate concentration as a function of electrical conductivity, dashed blue line is the statistical relationship based on the 1152 data set; B. Difference between calculated and measured bicarbonate concentration, median error on absolute value is provided.

Figure 6: A. SIc range of possible value from measured values (green parallelogram, Table 4) and SIc range of possible value from estimated values (violet parallelogram, Table 5) for the 6 February 2009 in Farfal spring (Cussac site) in the SIc-abacus built for a temperature of $12.4^{\circ} \mathrm{C}$ (measured temperature); $\mathrm{B}$. zoom on the parallelograms.

Figure 7: Farfal spring SIc: Blue line is the Sic variation with measured pH, bicarbonate and calcium concentrations, green area is the range of possible values considering the uncertainty on the measured values, orange line is the Sic variation with measured $\mathrm{pH}$ and estimated bicarbonate and calcium concentrations, violet area is the range of possible values considering the estimated values.

Figure 8 : Variation of the ranges of measured SIc and estimated or measured SIc, and the difference between the two SIc; Farfal spring on Cussac site and SAS1 spring on Lascaux site are added as examples.

Figure 9: SAS1 spring continuous measurements A. continuous (every 10min) measurements of electrical conductivity (violet) and $\mathrm{PcO}_{2} \mathrm{eq}$ (green) in SA1 spring (Lascaux site), calculated continuous measurement of bicarbonate concentration (orange) and field values of bicarbonate concentration (orange diamonds); $B$. Continuous measurement of pH (blue) and calculated pH (pink). 
Table 1 : Meteorological statistics on the four areas

Table 2 : Statistical description of the data set

Table 3 : Organization of the spreadsheet software for the building of SIc-Abacus.

Table 4: SIc values for the 6 February 2008 water sample in Farfal spring considering to the possible extreme values of measured $\mathrm{pH}$, bicarbonate and calcium; white background corresponds to the actual measured value, light grey background corresponds to the measured value minus the uncertainty, dark grey background corresponds to the measured value plus the uncertainty; blue SIc value come from the maximum possible value of bicarbonate, SIc values (in green) come from the maximum possible value of calcium and orange SIc values come from the maximum possible $\mathrm{pH}$;

Table 5 : Effects on SIc of the estimation of bicarbonate and calcium from measure of electrical conductivity; white background corresponds to the actual measured value, light grey background corresponds to the measured value minus the uncertainty, dark grey background corresponds to the measured value plus the uncertainty.

Table 6 : Comparison of "calculated-Sic" and "estimated-SIc" for Cussac and Lascaux site; for each site only 10 examples are randomly selected and presented. 
a) Lascaux cave karst system

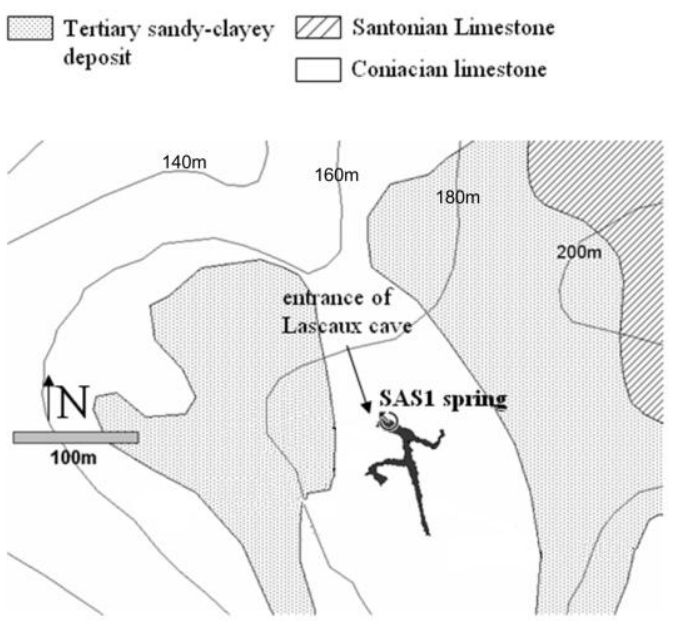

b) Cussac cave karst system Tertiary sandy-clayey $\square$ Campanian calcareous sandstone
deposit

D. Campanian marly limestone

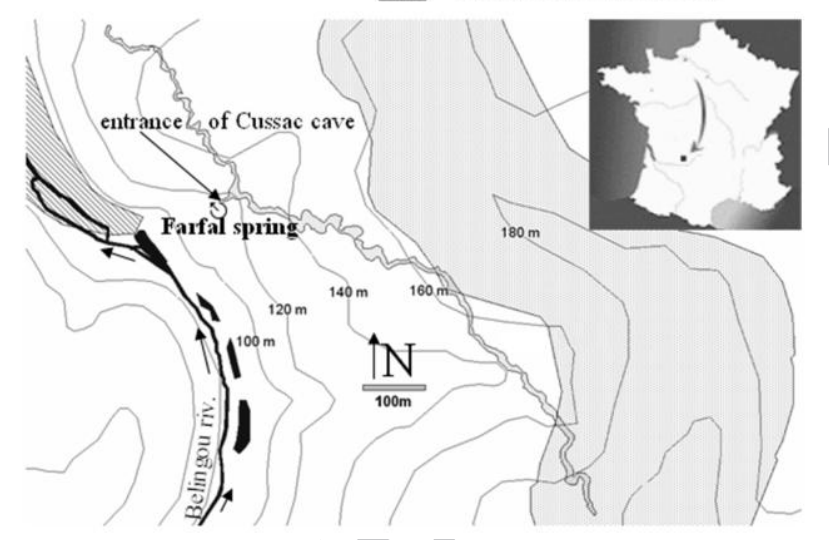




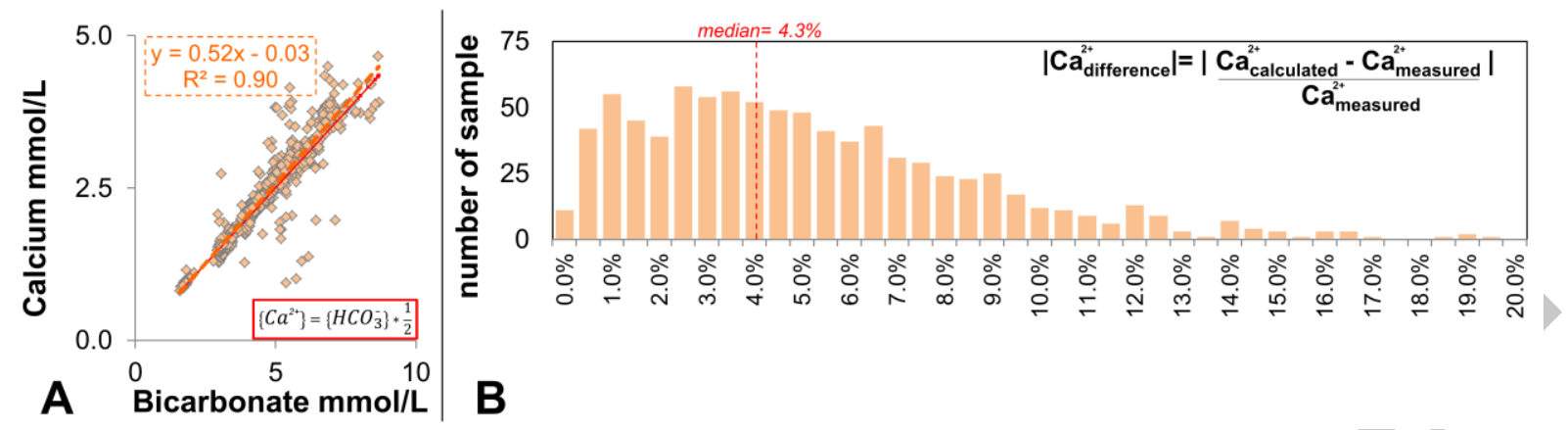




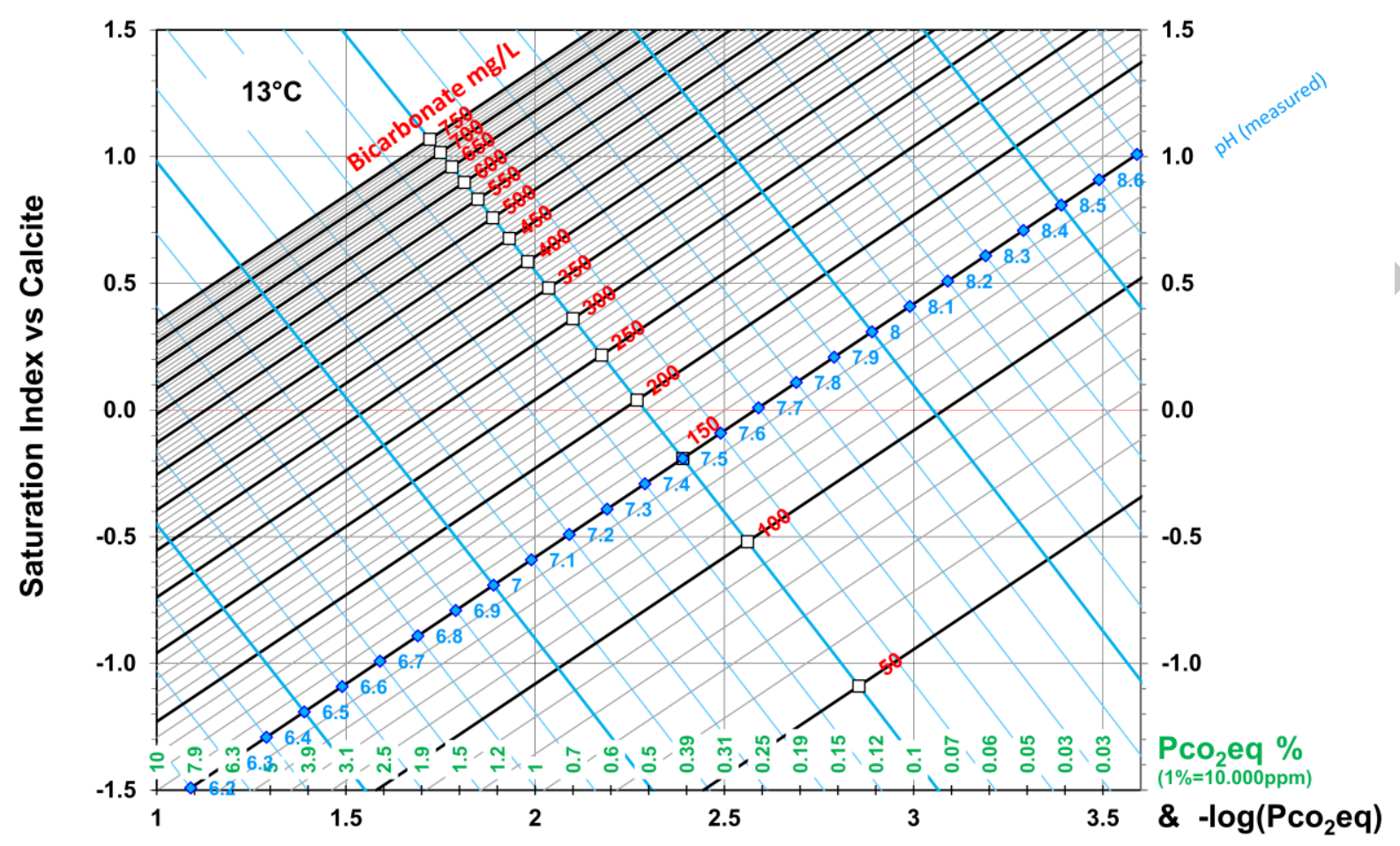




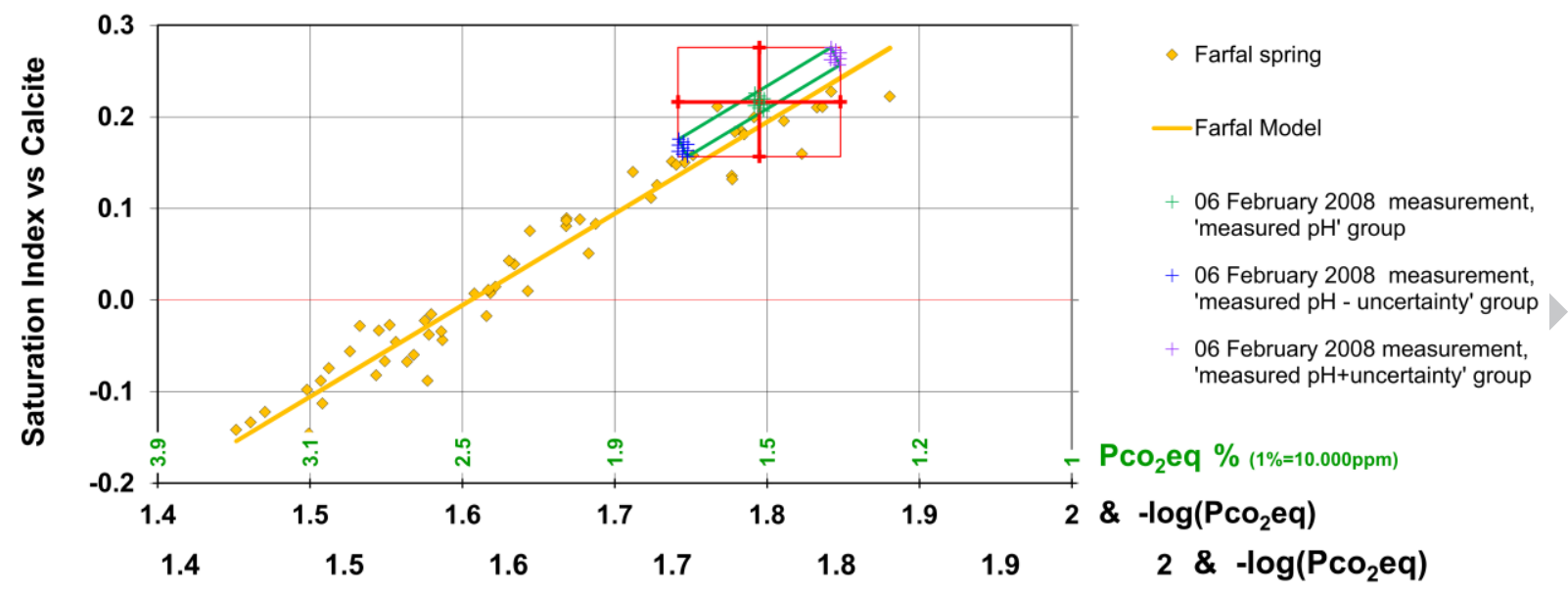




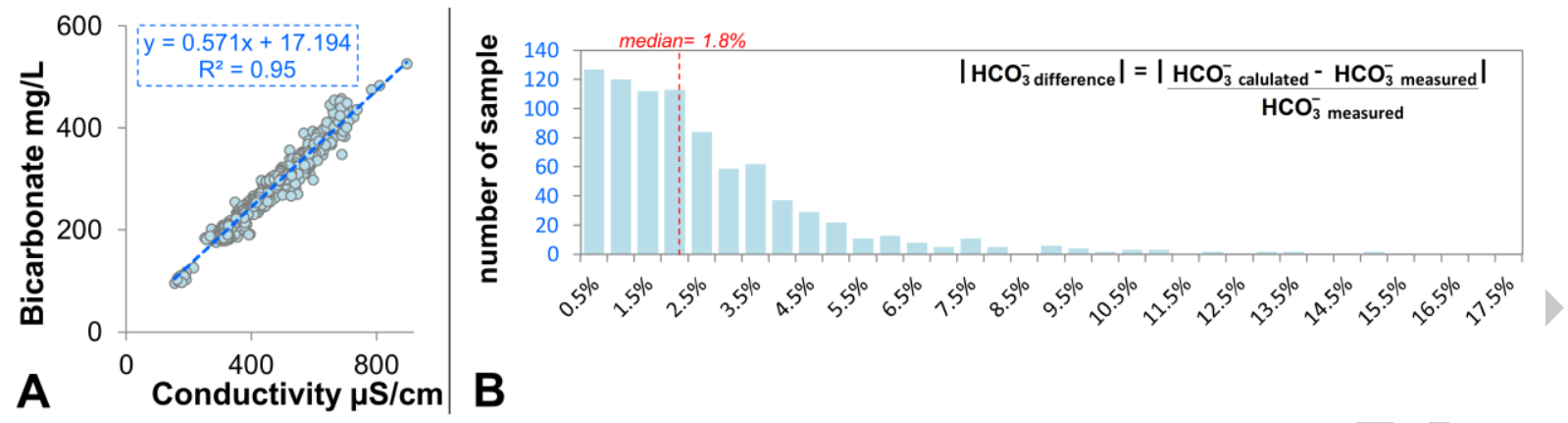




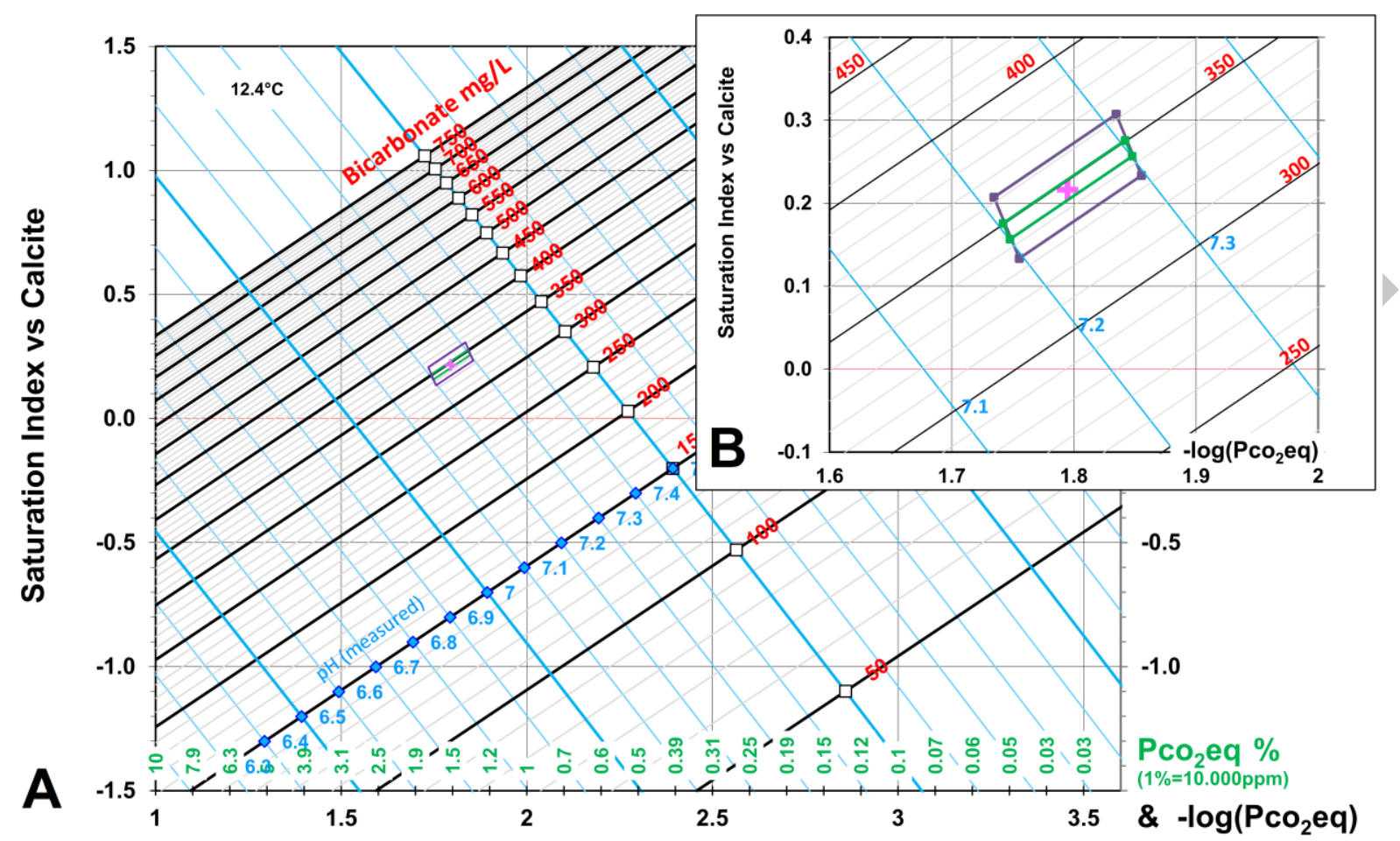



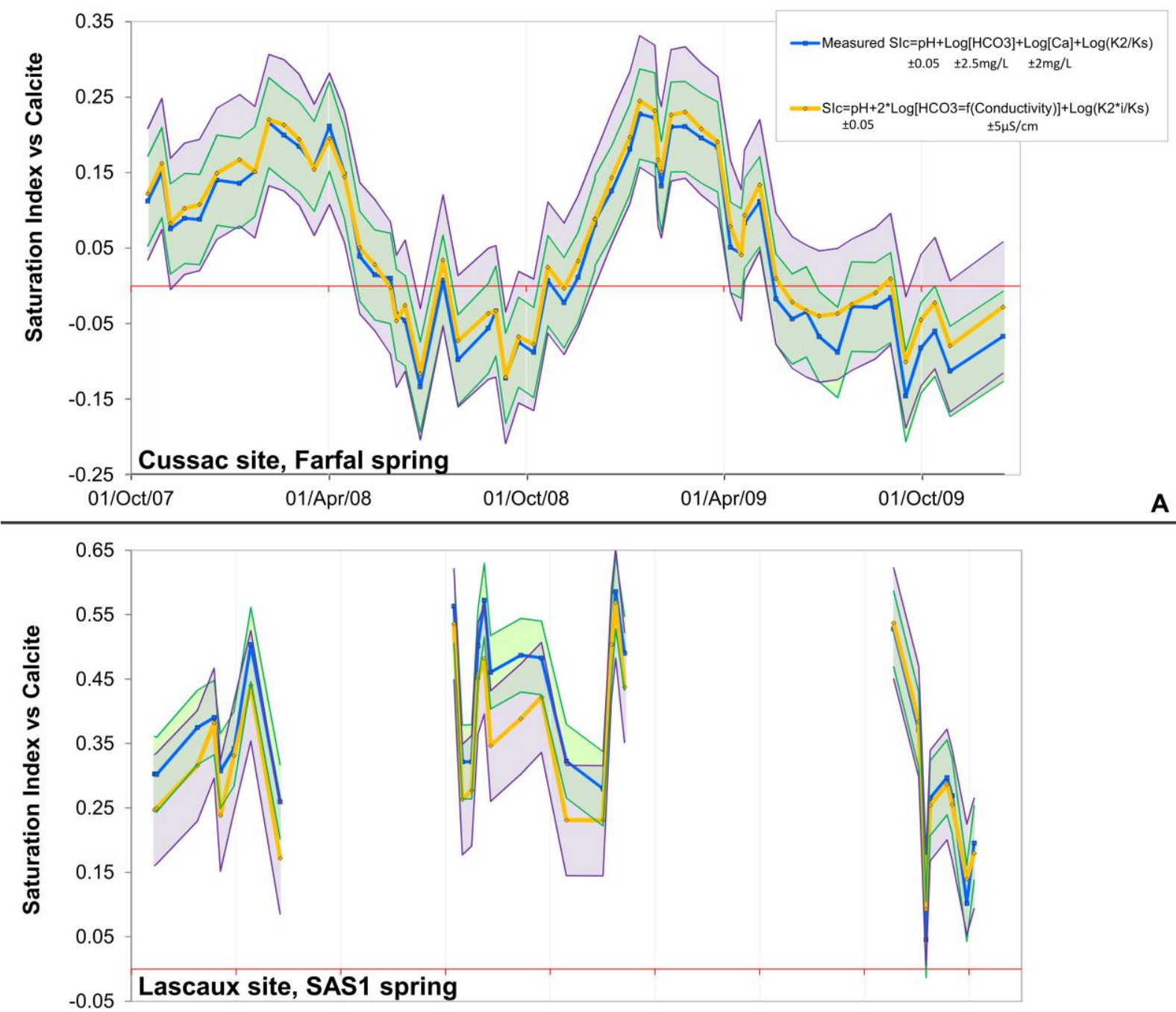

01/Jan/13 11/Apr/13 20/Jul/13 28/Oct/13 05/Feb/14 16/May/14 24/Aug/14 02/Dec/14 12/Mar/15 


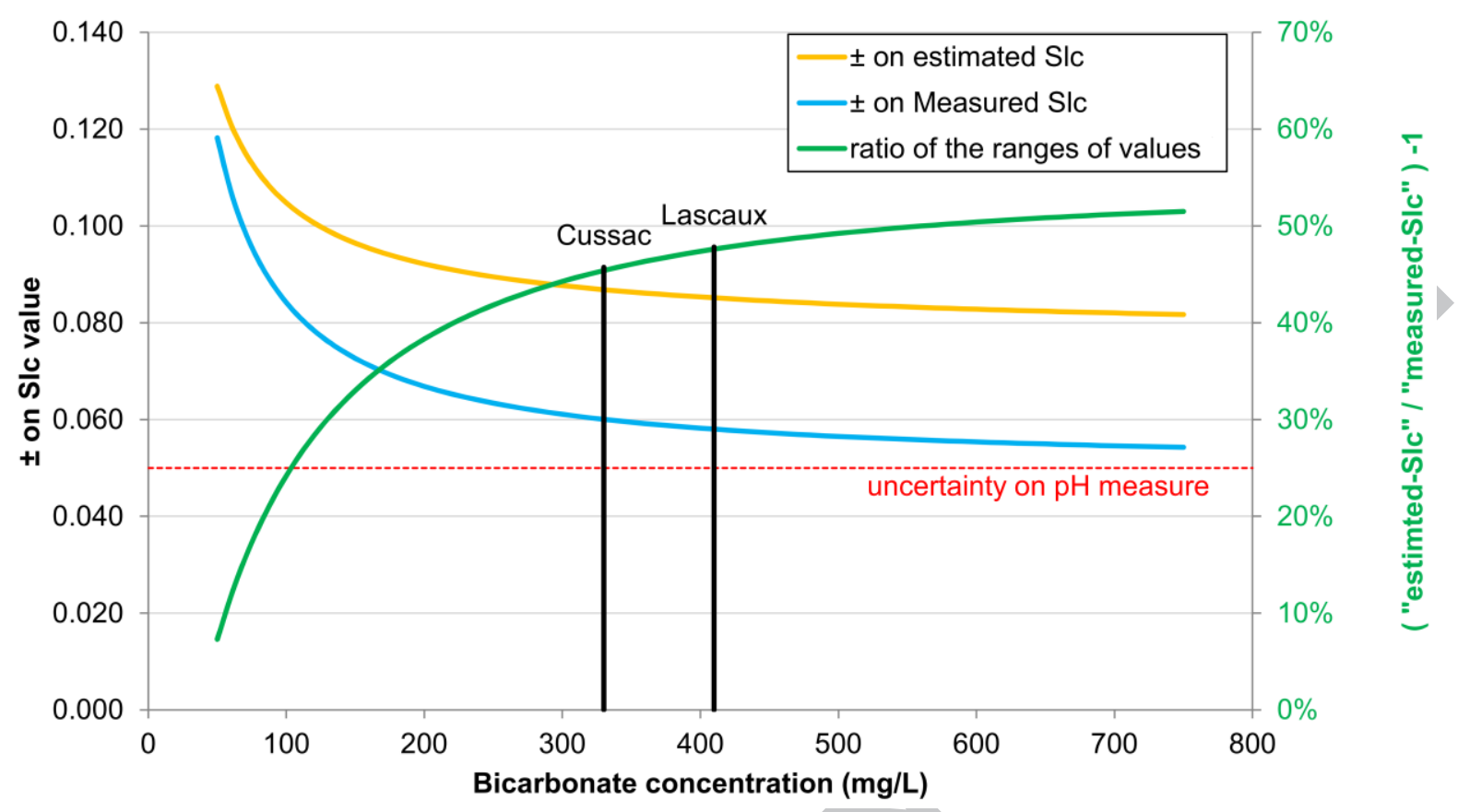



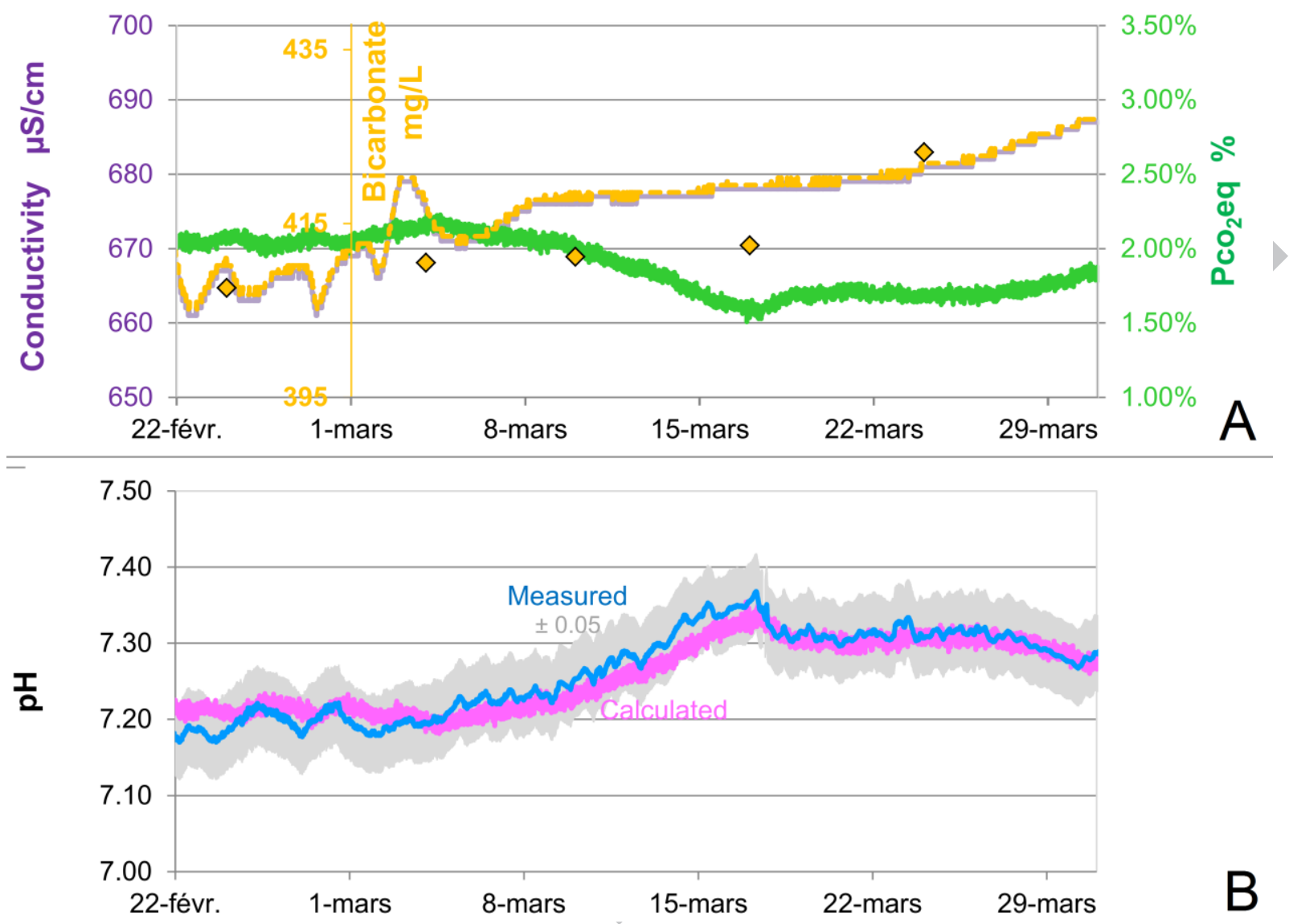


\begin{tabular}{|l|c|c|c|}
\hline Number of springs & \multicolumn{3}{|c|}{55} \\
\hline Number of samples & \multicolumn{3}{|c|}{1152} \\
\hline Oldest sample & \multicolumn{3}{|c|}{ Dec-1990 } \\
\hline Newest sample & \multicolumn{3}{|c|}{ Mar-2015 } \\
\hline & Min & Average & Max \\
\hline Bicarbonate (mg/L) & 96 & 261 & 529 \\
\hline Calcium (mg/L) & 33 & 87 & 197 \\
\hline Electrical conductivity $(\boldsymbol{\mu S} / \mathbf{c m})$ & 154 & 434 & 896 \\
\hline pH (pH units) & 6.638 & 7.522 & 8.620 \\
\hline Sic (pH units) & -0.842 & 0.215 & 1.139 \\
\hline Water temperature $\left({ }^{\circ} \mathbf{C}\right)$ & 2.5 & 12.3 & 25.3 \\
\hline
\end{tabular}




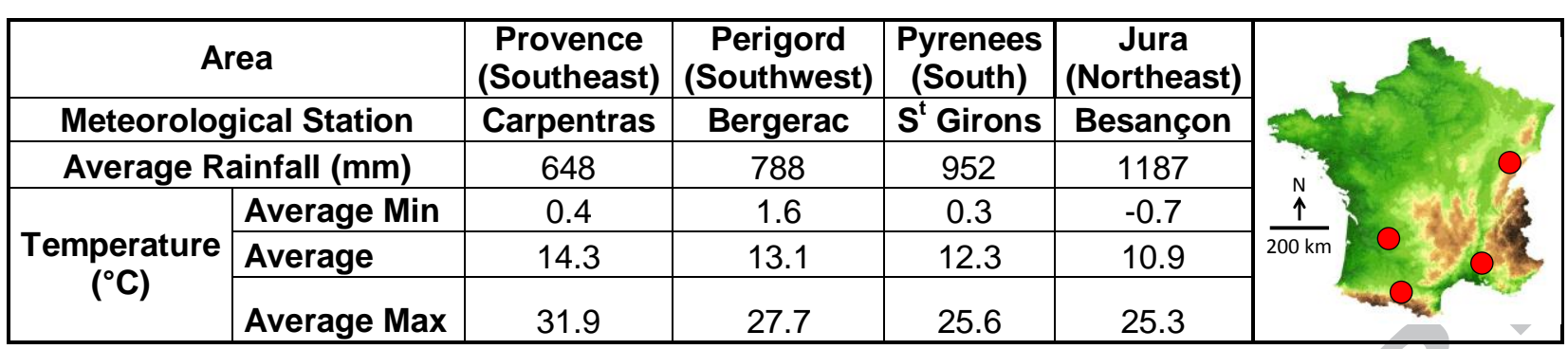




\begin{tabular}{|c|c|c|c|c|c|c|c|c|c|c|c|c|}
\hline 1 & 2 & 3 & 4 & 5 & 6 & 7 to 12 & 13 & 14 and 15 & 16 and 17 & 18 to 21 & 22 & 23 \\
\hline $\begin{array}{c}\text { Sample } \\
\text { I.D. }\end{array}$ & T kelvin & $X$ (conductivity) & $\mathrm{pH}$ & $\mathrm{HCO}_{3}^{-}$ & $\mathrm{Ca}^{2+}$ & $\begin{array}{l}\text { Other } \\
\text { ions }\end{array}$ & $\begin{array}{c}\text { Ionic } \\
\text { Strength }\end{array}$ & $\begin{array}{c}\text { Activity } \\
\text { coefficients }\end{array}$ & $\begin{array}{c}\text { Activity of } \\
\mathrm{HCO}_{3}^{-} \& \mathrm{Ca}^{2+}\end{array}$ & $\begin{array}{c}\text { Constants } \\
\mathrm{K}_{\mathrm{s}}, \mathrm{K}_{0}, \mathrm{~K}_{1}, \mathrm{~K}_{2}\end{array}$ & Slc & $-\log \left(\mathrm{PcO}_{2} \mathrm{eq}\right)$ \\
\hline & & & & & & & eq. 1 & eq. 2 & eq. 3 & & eq. 6 & eq. 7 \\
\hline & & & & & & & & & & & & \\
\hline
\end{tabular}




\begin{tabular}{|c|c|c|c|c|}
\hline $\begin{array}{c}\mathrm{pH} \pm 0.05 \\
\mathrm{pH} \text { unit }\end{array}$ & $\begin{array}{c}\mathrm{HCO}_{3}^{-} \pm 2.5 \\
\mathrm{mg} / \mathrm{L}\end{array}$ & $\begin{array}{c}\mathrm{Ca}^{2+} \pm 2 \\
\mathrm{mg} / \mathrm{L}\end{array}$ & $\begin{array}{c}\text { (Slc measured) - (Slc extreme values) } \\
\text { pH unit }\end{array}$ & \\
\hline 7.21 & 348 & 112 & 0.060 & \multirow{9}{*}{ 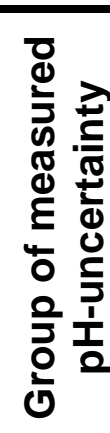 } \\
\hline 7.21 & 348 & 114 & 0.053 & \\
\hline 7.21 & 348 & 116 & 0.046 & \\
\hline 7.21 & 351 & 112 & 0.057 & \\
\hline 7.21 & 351 & 114 & 0.050 & \\
\hline 7.21 & 351 & 116 & 0.043 & \\
\hline 7.21 & 353 & 112 & 0.054 & \\
\hline 7.21 & 353 & 114 & 0.047 & \\
\hline 7.21 & 353 & 116 & 0.041 & \\
\hline 7.26 & 348 & 112 & 0.010 & \multirow{9}{*}{ 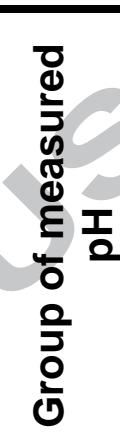 } \\
\hline 7.26 & 348 & 114 & 0.003 & \\
\hline 7.26 & 348 & 116 & -0.004 & \\
\hline 7.26 & 351 & 112 & 0.007 & \\
\hline 7.26 & 351 & 114 & 0.000 & \\
\hline 7.26 & 351 & 116 & -0.007 & \\
\hline 7.26 & 353 & 112 & 0.004 & \\
\hline 7.26 & 353 & 114 & $=0.003$ & \\
\hline 7.26 & 353 & 116 & -0.009 & \\
\hline 7.31 & 348 & 112 & -0.040 & \multirow{9}{*}{ 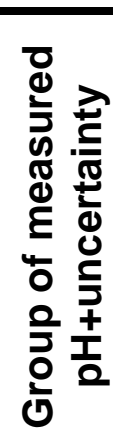 } \\
\hline 7.31 & 348 & 114 & -0.047 & \\
\hline 7.31 & 348 & 116 & -0.054 & \\
\hline 7.31 & 351 & 112 & -0.043 & \\
\hline 7.31 & 351 & 114 & 05 & \\
\hline 7.31 & 351 & 116 & -0.057 & \\
\hline 7.31 & 353 & 112 & -0.046 & \\
\hline 7.31 & 353 & 114 & -0.053 & \\
\hline 7.31 & 353 & 116 & -0.059 & \\
\hline
\end{tabular}




\begin{tabular}{|c|c|c|c|c|c|}
\hline $\begin{array}{c}\mathrm{pH} \pm 0.05 \\
\mathrm{pH} \text { unit }\end{array}$ & $\begin{array}{c}\mathrm{X}, \text { Conductivity } \pm 5 \\
\mu \mathrm{S} / \mathrm{cm}\end{array}$ & $\begin{array}{c}\mathrm{HCO}_{3}^{-}=f(X) \pm 1.8 \% \\
\mathrm{mg} / \mathrm{L}\end{array}$ & $\begin{array}{c}\mathrm{Ca}^{2+}=\mathrm{f}\left(\mathrm{HCO}_{3}^{-}\right) \pm 4.3 \% \\
\mathrm{mg} / \mathrm{L}\end{array}$ & \multicolumn{2}{|c|}{$\begin{array}{l}\text { (Slc measured) - (Slc extreme values) } \\
\text { pH unit }\end{array}$} \\
\hline 7.26 & 584 & 351 & 114 & 0.000 & reference $=$ measure \\
\hline 7.26 & 584 & 351 & 115 & 0.004 & estimation \\
\hline 7.26 & 589 & 354 & 116 & 0.010 & effect of $X$ augmented \\
\hline 7.26 & 584 & 357 & 117 & 0.018 & effect of $\mathrm{HCO}_{3}$ augmented \\
\hline 7.26 & 584 & 351 & 120 & 0.020 & effect of $\mathrm{Ca}$ augmented \\
\hline 7.26 & 589 & 360 & 123 & 0.040 & cumulated effects \\
\hline 7.26 & 579 & 348 & 114 & -0.003 & effect of $X$ diminished \\
\hline 7.26 & 584 & 344 & 113 & -0.010 & effect of $\mathrm{HCO}_{3}$ diminished \\
\hline 7.26 & 584 & 351 & 110 & -0.013 & effect of $\mathrm{Ca}$ diminished \\
\hline 7.26 & 579 & 342 & 107 & -0.034 & cumulated effects \\
\hline 7.21 & 589 & 360 & 123 & -0.010 & all augmented \\
\hline 7.21 & 579 & 342 & 107 & -0.084 & all diminished \\
\hline 7.31 & 589 & 360 & 123 & 0.090 & all augmented \\
\hline 7.31 & 579 & 342 & 107 & 0.016 & all diminished \\
\hline
\end{tabular}




\begin{tabular}{|c|c|c|c|c|}
\hline Site & Date & « measured-SIc» & « estimated-Slc » & $\begin{array}{c}\text { Difference } \\
\text { Measured - Estimated }\end{array}$ \\
\hline Cussac & Nov-2007 & 0.075 & 0.083 & -0.007 \\
\hline Cussac & Dec-2007 & 0.140 & 0.149 & -0.009 \\
\hline Cussac & Jun-2008 & -0.046 & -0.026 & -0.020 \\
\hline Cussac & Sep-2008 & -0.122 & -0.121 & -0.001 \\
\hline Cussac & Sep-2008 & -0.074 & -0.067 & -0.007 \\
\hline Cussac & Oct-2008 & -0.088 & -0.077 & -0.011 \\
\hline Cussac & Apr-2009 & 0.051 & 0.079 & -0.028 \\
\hline Cussac & Jun-2009 & -0.044 & -0.021 & -0.022 \\
\hline Cussac & Sep-2009 & -0.146 & -0.101 & -0.045 \\
\hline Cussac & Oct-2009 & -0.082 & -0.045 & -0.037 \\
\hline \multicolumn{2}{|c|}{$R^{2}$ Cussac = 0.99} & \multicolumn{2}{|c|}{ average difference on Cussac } & -0.015 \\
\hline Lascaux & Mar-2013 & 0.375 & 0.316 & 0.059 \\
\hline Lascaux & Mar-2013 & 0.308 & 0.238 & 0.069 \\
\hline Lascaux & Nov-2013 & 0.563 & 0.536 & 0.027 \\
\hline Lascaux & Nov-2013 & 0.322 & 0.263 & 0.058 \\
\hline Lascaux & Dec-2013 & 0.461 & 0.347 & 0.114 \\
\hline Lascaux & Feb-2014 & 0.323 & 0.231 & 0.092 \\
\hline Lascaux & Apr-2014 & 0.490 & 0.438 & 0.053 \\
\hline Lascaux & Dec-2014 & 0.531 & 0.537 & -0.006 \\
\hline Lascaux & Jan-2015 & 0.049 & 0.093 & -0.044 \\
\hline Lascaux & Feb-2015 & 0.301 & 0.287 & 0.014 \\
\hline \multicolumn{2}{|c|}{$R^{2}$ Lascaux $=0.91$} & \multicolumn{2}{|c|}{ average difference on Lascaux } & 0.039 \\
\hline \multicolumn{2}{|c|}{$R^{2}$ data set $=0.85$} & \multicolumn{2}{|c|}{ average difference on the data set } & 0.077 \\
\hline
\end{tabular}




\section{Nicolas PEYRAUBE}

nicolas.peyraube@u-bordeaux.fr

Tel.: 05.40.00.88.41

Bordeaux, 04/10/2018

\section{Article Highlights}

Sic-Abacus: An in-situ tool for estimating SIC and $\mathrm{PCO}_{2}$ in the context of carbonate karst

- From calcite equilibrium equations, an abacus is built in the SIc $=f\left(\mathrm{Pco}_{2} \mathrm{eq}\right)$ reference frame. The abacus is named SIcAbacus.

- Calculation for Saturation index with respect to calcite (SIc) is detailed. The range of values of SIc is discussed according to the uncertainty on $\mathrm{pH}$, bicarbonate and calcium concentrations.

- Consequences on SIc estimation of field estimations of bicarbonate and calcium concentrations from electrical conductivity are discussed. 
- Comparison of "measured SIc" and "estimated-SIc" on Cussac and Lascaux sites gave a goodness of fit of $\mathrm{R}^{2}=0.99$ and $\mathrm{R}^{2}=0.91$.

- The SIc-Abacus can be used on field for decision making and is not aimed to replace complete calculation if SIc is needed for further studies. 